Article

\title{
Linguistic Decipherment of the Lettering on the (Original) Carving of the Virgin of Candelaria from Tenerife (Canary Islands)
}

\author{
Vicente Jara Vera * (1) and Carmen Sánchez Ávila \\ Department of Applied Mathematics to Information Technology and Communications, Polytechnical University \\ of Madrid, Avenida Complutense no. 30, Madrid 28040, Spain; carmen.sanchez.avila@upm.es \\ * Correspondence: vicente.jara@upm.es; Tel.: +34-686-615-535
}

Received: 12 June 2017; Accepted: 25 July 2017; Published: 30 July 2017

\begin{abstract}
The wooden carving of Our Lady of Candelaria, discovered in the municipality of the same name on the island of Tenerife (Canary Islands) during the first half of the fifteenth century, had nearly two hundred letters of the Latin alphabet inscribed on her garments. Unfortunately the original carving disappeared after the storm that took place in 1826. Once the original letters on the first image were discovered by means of analysing both textual and artistic documentation and sources, we conclude that the text is archaic-Berber language used by the islanders, Insular-Amazigh, which no longer exists in the present day. Having discussed lexical, morphological, syntactic and phonetic aspects of this archaic language, as well as conducted a semantic analysis of the carving both from the native aboriginal perspective and the Christian one, we expound here our proposal of the meaning of the letters engraved on the Marian carving of Candelaria from its lexical voices and roots of their Berber and Insular-Amazigh languages, with the previous proposed solutions.
\end{abstract}

Keywords: Insular-Amazigh; archaic-Berber; linguistic decipherment

\section{Introduction}

There is a carving of the Virgin of Candelaria in the Canary Islands-on the island of Tenerife to be precise-which can be found in the municipality also known as Candelaria (Vera 2016). However, it must be noted that such carving is not the original and first one, since the original was lost during a heavy storm on the island in 1826 (Vera 2016, pp. 147-62).

One of the most striking features of that first image is that it had a set of nearly two hundred letters on it-181 to be exact-, Latin capital letters which had been written on different parts of the clothing and figure (Vera 2016, pp. 13-146). Their meaning remains unknown to this day, forming an inscription which dates back to the time the carving itself was delivered, at some point between the fourteenth and fifteenth centuries as it has been estimated (Vera 2016, pp. 163-225).

(Neckline) TIEPFSEPMERI.

(Girdle) NARMPRLMOTARE.

(Cuff on the candle's side) LPVRINENIPEPNEIFANT.

(Right side of the cape) OLM INRANFR IAEBNPFM RFVEN NVINAPIMLIFINVIPI NIPIAN.

(Left side of the cape) FVPMIRNA ENVPMTI EPNMPIR VRVIVINRN APVIMFRI PIVNIAN NTRHN.

(Garment edge) EAFM IRENINI FMEAREI.

(Back of the cape) NBIMEI ANNEIPERFMIVIFVF.

Once the original letters on the first image were discovered-by means of analysing both textual and artistic documentation and sources-and having reached the conclusion that the letters gathered by fray Alonso de Espinosa, O.P. (1543-ca. 1600) in his work On the origin and miracles of the Sacred 
Image of Our Lady of Candelaria, which was found on the island of Tenerife, along with the description of this Island (1594) (Del origen y milagros de la Santa Imagen de nuestra Señora de Candelaria, que apareció en la Isla de Tenerife, con la descripción de esta Isla) (de Espinosa [1594] 1980; Vera 2016, pp. 139-46)) are the main and most reliable reference for the inscription, we must place the image in its context, as well as its connection with the conquest (accomplished at the end of the sixteenth century) and the evangelisation of the Canary Islands, its connection with the hermit Franciscan friars-especially the ones who evangelised that region-, the attempts at inculturating the canarian native deities, which had a continental Libyco-Berber origin, into the Christian worldview, in order to comprehend the potential significance of the image (Figure 1), its Mariological sense and the semantics of the inscription on it (Vera 2016, pp. 163-226, 799-994).

At first, we tried to categorise the words on the image under some existing language, taking into account every possible variation: Indo-European, Uralic, Altaic, Caucasian, Afroasiatic, Nilo-Saharan, Niger-Congo, Khoisan and Austronesian, together with unclassified languages (Basque and Etruscan), a total of 101 languages with 261 texts, as related to the period being studied as possible in terms of its making, the fourteenth and fifteenth century. Unfortunately, the fact that they did not belong to any language was confirmed (Vera 2016, pp. 227-576).

After examining the linguistic text, a detailed and thorough cryptological study was conducted, assuming an encrypted text, and taking into account the possible cryptological systems that had been employed in order to generate the text of the inscription. Once the study was completed, it could be verified that the set is neither the result of an encryption process nor that of a concealing one (Vera 2016, pp. 577-787).

The only possibility left was that the text consisted of a pseudo-random and meaningless generation of letters and, therefore, it lacked any kind of semantics, but analyses proved the contrary: the text has its own linguistic structure (Vera 2016, pp. 788-98).

At this point, and having thoroughly analysed every possibility and hypothesis, each one of them having been refuted, and reconsidering the body of speculations and assumptions once again, the Berber ethnographic and linguistic scope was evaluated in depth as the most plausible and probable hypothesis, since the data provided by different disciplines (genetic, historical, archaeological, artistic, linguistic ... ) suggest an arrival of settlers, perhaps in several stages, to the Canary Islands, at some point between the first century $\mathrm{BC}$ and the first century $\mathrm{AD}$. Nevertheless, prior contact with the coastal areas of the islands which were further to the east had already occurred (Vera 2016, pp. 799-819).

Finally, we conclude that the text of the original image of Candelaria is the product of putting the sounds heard by evangelist friars into writing by means of either Roman or Latin graphemes; these sounds belonged to the archaic-Berber language used by the islanders, which no longer exists in the present day. Indeed, we could not detect it during the linguistic analysis, and despite of the fact that we even compared it with the current Berber linguistic Family, from which we studied 18 languages (Awdjila, Sokna, Siwa, Kabyle, Tashelhiyt, Djerba, Djebel Nefusa, Ghomara, Ghadames, Teggargrent, Figuig, Tarifiyt, Chaouia, Adagh Tuareg, Taneslemt Tuareg, Ayer Tuareg, Zenaga and even Guanche), since due to evolution and contamination (mostly from the Arabic language), we were unable to observe its belonging to such Group (Vera 2016, pp. 819-965).

Having discussed lexical, morphological, syntactic and phonetic aspects of this archaic language, as well as conducted a semantic analysis of the carving both from the native aboriginal perspective and the Christian one, we will now expound the meaning of the letters engraved on the Marian carving of Candelaria from its lexical voices and roots of their Berber and Insular-Amazigh languages (Vera 2016, pp. 967-94). 


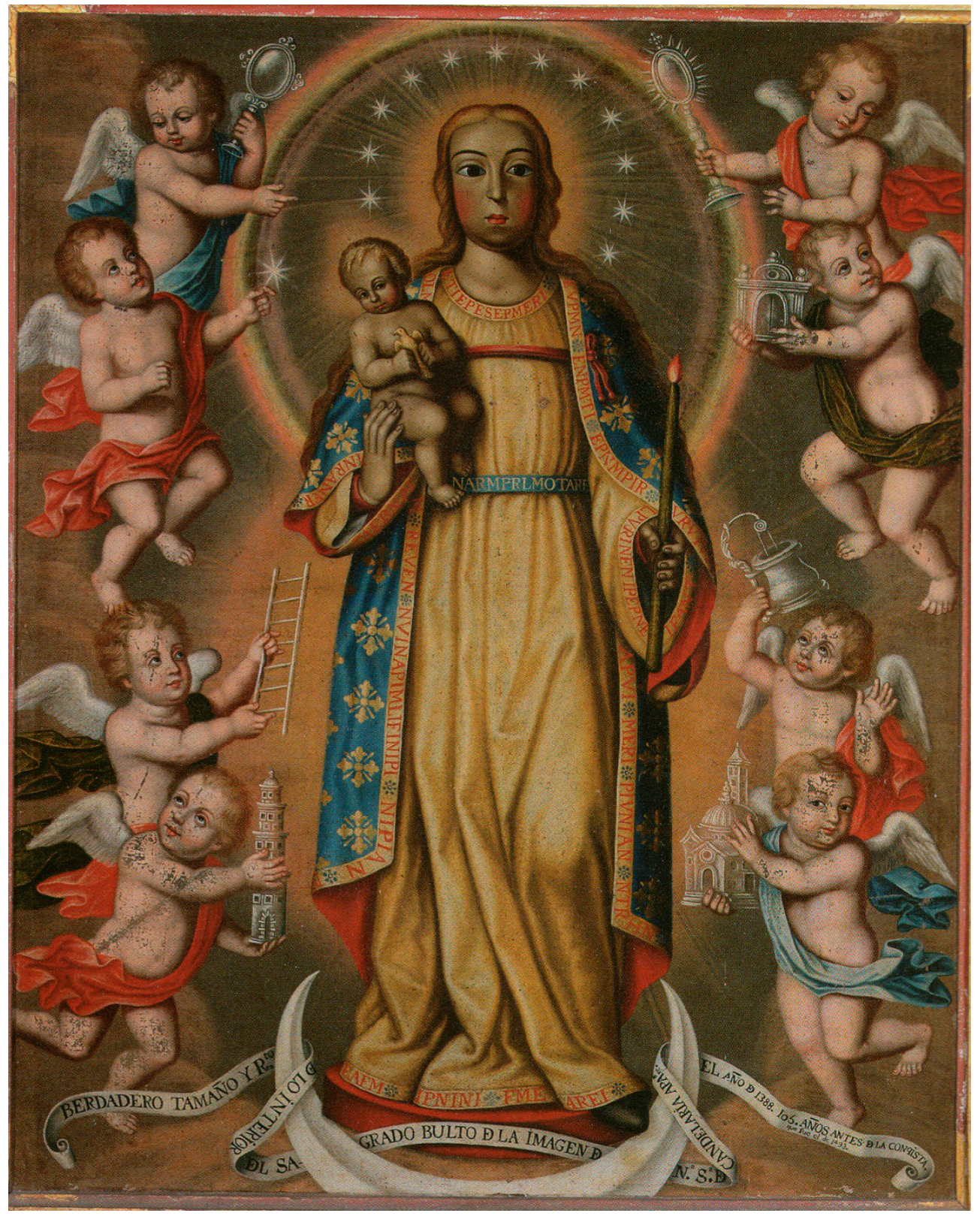

Figure 1. Virgin of Candelaria. ¿Nicolás de Medina Villavicencio? 1730-1750. Private collection (Tenerife) (Morales 2009).

\section{Previous Proposed Solutions}

We will now briefly compile the proposed ways to understand the inscription at different points in history, which were generally barely applicable because of their vagueness, in spite of being the result of the efforts of many illustrious and conscious scholars over the course of the years. Notwithstanding that, we will close our dissertation with a highly competitive proposal, which we consider to be in line with the Amazigh or Berber context, and which has been a major milestone in the decipherment of the Marian inscription of Candelaria.

1. The first known solution belongs to Gonzalo Argote de Molina (1548-1596) and were gathered by Juan de Abreu Galindo, O.F.M. (ca. 1535-?) in History of the conquest of the seven Canary Islands (1676) (Historia de la conquista de las siete Islas de Canaria), a sort of Latin acronyms of devotional fervour which are applied to four incomplete fragments (Abreu Galindo [1676] 1977). 
Thus, for example, was proposed as the solution to the text on the neckline, TIEPFSEPMERI: Illustrata Es Patri Filio Spiritu-santo Et Pia Mater Eiusdem Redemptoris Iesu. Or for the lettering on the girdle, NARMPRLMOTARE: Nostrum Altissimum Regem Maria Peperit Reddidit Libertatem Maria Omnibus Tortis A Rege Erebia. We will leave it here, as we consider this is a sufficiently good illustration of the way to solve the textual group, and which has been broadly discussed already (Vera 2016, pp. 42-46, 73-74).

2. The proposal by Athanasius Kircher, S.I. (1602-1680), gathered by Jesús Alonso de Andrade, S.I. (1590-1672) in Universal Patronage of the Holy Virgin Mary, Mother of God and our Lady (1664) (Patrocinio universal de la santissima Virgen Maria, Madre de Dios, y Señora Nuestra), and Juan Núñez de la Peña (1641-1721) in Conquest and antiquities of the island of Gran Canaria and its description, along with many warnings about its privileges, conquerors, settlers and other special features in the highly powerful island of Tenerife, addressed to the miraculous image of Our Lady of Candelaria (1676) (Conquista y antigüedades de la isla de la Gran Canaria y su descripción, con muchas advertencias de sus privilegios, conquistadores, pobladores y otras particularidades en la muy poderosa isla de Tenerife, dirigido a la milagrosa imagen de Nuestra Señora de Candelaria), assuming an Arabian linguistic origin for pious purposes only, without any scientific contribution whatsoever (de Andrade 1664; de Béthencourt Massieu 2004; Núñez de la Peña 1676; Vera 2016, pp. 51-55, 74-75).

Thus, we give the examples of the neckline and the girdle again: TIEPESEPMERI: Insignes Matris/Tipus Matris. In the case of the girdle, with the letters NARMPRLOTARE: Pro nobis ora, vel advocatio/Pro novis ora, vel advocate.

3. Other proposals are the Latin acronyms and pseudo-acronyms by Bartolomé García Ximénez (1622-1690), who never intended to solve the conundrum of the lettering but to offer a compilation of pious and devotional lists to the people that, astonished, went to visit the Marian carving (Moure 1991, pp. 49-54; Vera 2016, pp. 55, 60, 75-76).

Again, we compile those corresponding to the neckline and to the girdle of the statue, in the form of example of how he proceeded: ETIEPESEPMERI: Eccleciae Triumfantis In Excelsis \{Preposita/Praeposita\} Electa Sanctorum Et Patrona Militantis Ecclesiae Romanae \{Infalibilis/Indefectibilis\}. NARMPRLMOTARE: Non Ambio Regnorum Magna Palatia Requiro Litora Maris Oceani \{Thenerifensis/Thenerifensia\} Ad Rusticos Edocendos.

4. John Campbell (1840-1904) made a striking contribution, in Archaic-Basque language and with Etruscan and Iberian influences. Utterly surprising in its conclusion, we give the plain example of the fragments on the neckline and the girdle: (Campbell 1901; Vera 2016, pp. 77-78):

TIEPFSEPMERI on the neckline, conveying the words: ko i en tu po no en tu me ne ra au: Koi entu pono entu Menera au (Desire hear grief hear Menera this): Let this (goddess) Menera hear the prayer, hear the sorrow (Campbell 1901, p. 60; Vera 2016, p. 77).

Or, on the girdle: (M/N) ARMPRLMOTARE, mi ra er mi to ri se me ma gu re er en: mira erimi etorri seme etna gure erren (spectacle cause place come son give our compassion): Coming to cause to set up a spectacle, to give the son our compassion (Campbell 1901, p. 61; Vera 2016, pp. 77-78).

5. An additional proposed solution was given by Antonio María Manrique (1837-1907), who assumes it is in the Semitic Language, by gathering biblical passages or devotional Christian ones, which applies to two fragments on the garment. To be precise, the lettering on the neckline supposedly must convey the name of the represented figure, and so we might expect to find something like Mary, full of grace, whereas, on the girdle, we could expect it to mean One God and Father of all, without further contributions or base for his hypotheses (Manrique 1898; Vera 2016, p. 79).

6. Another suggestion, including a syncretic combination of Spanish, Portuguese and Italian, is the one proposed by Alonso Ascanio y Negrín (1855-1936), who provides the meaning ME SOBRA O GAJE for the neckline, EVIIOJ DE NOVIA for the girdle, or even the author and date LA FIXE SINESIVJ ZEA MCCXLIX for the back of the cape (Negrín 1899; Vera 2016, p. 80). 
7. Yet another proposal comes from Fidel Fita Colomé, S.I. (1845-1918) (Moure 1991, pp. 65-67; Vera 2016, pp. 80-81), a transposition of the Latin language highly modified into a biblical sense, even though he worked on one fragment of the inscriptions only, the one on the neckline to be exact, ETIEPESEPMERI, which offers the redistribution of the text Sepi et eripe me (protect and rescue me), referring to the invoking of the litany Turris eburnea (ivory tower) according to the Song of Songs 8, 4 (Bible 1611, p. 3L6r), or rather, Cant 4, 4 (Bible 1611, p. 3L5r) or Isaiah 5, 2, which reads Et sepivit eam, [...] et aedificavit turrim (and gathered out the stones thereof (the vineyard) [...] and built a tower) (Bible 1611, p. 3M2v; Moure 1991, pp. 65-67; Tvveedale 2005, p. 835).

8. Lastly, the multi-pseudo-acronyms from Latin and Spanish carrying religious meaning about three fragments, by José Hernández Morán (1922-) which, by way of example, we provide for the lettering on the neckline only, where two interpretations are possible: on the one hand, the sub-division TI-E-PE-SEP-MERI, resulting in the phrase Forever you are Mary (Tú eres por siempre Maria), from Kircher's variation, or else, the more unnatural form TI-ERES-EP-MERI, that is, You are a mother's mirror (Tú eres espejo de madre), which is intended to be shown in the same semantic line as Tipus Matris (Image of the Mother) by the Jesuit (Morán 1957; Vera 2016, p. 81).

Once thoroughly examined (Vera 2016, pp. 73-84) and as we progressed with our linguistic and cryptanalyitic analysis, all of them became disregarded. None of them is worth further dedication, but they remain as a collection of possible solutions proposed over the course of history, and examples of how to solve a problem that, as has been clearly demonstrated, is extremely complex. Next, we will move on to a proposal for solution which differs widely from every other proposal we have discussed up to this point.

\section{The Insular-Amazigh Proposal}

The following proposal was made by the philologist and historiographer Ignacio Reyes García (1962-), today's main expert in the Amazigh language, and was expounded in the year 2007 (García 2010). This solution follows the same line as the conclusions we expound and share about the text on the carving of Our Lady of Candelaria being written in the Amazigh language from the Canary Islands, the Insular-Amazigh language.

We will reproduce his proposal by explaining every fragment on the garment in the first place, followed by its graphemes, the sequence of lexemes and the semantic meaning of each sequence.

(Neckline) TIEPFSEPMERI. <Ti yebb f săb Meri>. [T·Y]-[B·B]-[F]-[S·B]. (The Father under the protection of the Virgin Mary) (García 2011, pp. 414-15).

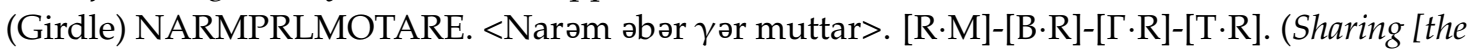
food] is an obligation towards the poor) (García 2011, p. 313).

(Cuff on the candle's side) LPVRINENIPEPNEIFANT. [L·W]-[R·N]-[B·B]-[N]-[F]-[N.T]. (Be merciful in the victory Lord of the eternal light) (García 2011, p. 289).

(Right side of the cape) OLM INRANFR IAEBNPFM RFVEN NVINAPIMLIFINVIPI NIPIAN. [L]-[M] [N]-[R]-[N.F.R] [N·B $(\mathrm{W})]-[\mathrm{F}]-[\mathrm{M}][\mathrm{R}]-[\mathrm{F} \cdot \mathrm{W}][\mathrm{G}]-[\mathrm{N} \cdot \Gamma]-[\mathrm{B} \cdot \mathrm{B}]-[\mathrm{M}]-[\mathrm{L} \cdot \mathrm{F}]-[\mathrm{N}]-[\mathrm{B} \cdot \mathrm{B}]$ $[\mathrm{N} \cdot \mathrm{Y}]-[\mathrm{B} \cdot \mathrm{B}]-[\mathrm{N}]$. (Your heart houses the most important treasure, Child Yahweh over you, shining treasure. A burden upon our conscience is like a stack over our shoulders. Control such burden) (García 2011, p. 319).

(Left side of the cape) FVPMIRNA ENVPMTI EPNMPIR VRVIVINRN APVIMFRI PIVNIAN NTRHN. $<$ Ffu b-mirna. Nubi am ti ewen am bir ur wiwi-n rn, abu i məfri. Bib-wən əyyan nut ər $\gamma$

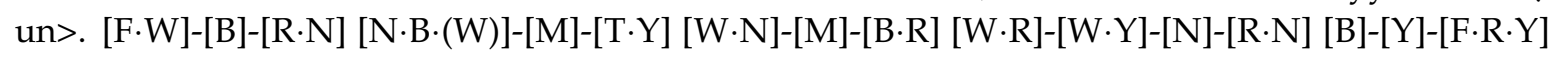
$[\mathrm{B} \cdot \mathrm{B}]-[\mathrm{W} \cdot \mathrm{N}]-[\mathrm{Y} \cdot \mathrm{W} \cdot \mathrm{N}][\mathrm{N} \cdot \mathrm{T}]-[\mathrm{R} \cdot \mathrm{\Gamma}]$. (It is dawning, great power. The Child just like the Father and the way of perfection avoid illness, and are a balm for those who suffer. Your only burden must be a shining candle) (García 2011, p. 207).

(Garment edge) EAFM IRENINI FMEAREI. <E af-m irenni f-əme arey>. [E]-[F]-[M] [R-N] [F]-[M·Y]-[R·Y]. (Oh, finding you increases the protection against superstition!) (García 2011, pp. 183-84). 
(Back of the cape) NBIMEI ANNEIPERFMIVIFVF. <Nəbbi y əməyyi. An-năy əberref mi əwif Uf>. $[\mathrm{N}]-[\mathrm{W} \cdot \mathrm{Y}]-[\mathrm{Y}]-[\mathrm{Y}][\mathrm{D}]-[\mathrm{N}]-[\mathrm{Y}]-[\mathrm{B} \cdot \mathrm{R} \cdot \mathrm{F}]-[\mathrm{M}]-[\mathrm{W} \cdot \mathrm{F}]-[\mathrm{F}]$. (We give refuge to that who ignores. We will forgive the offense whenever it is caused by the fear of God) (García 2011, pp. 313-14).

If we pay attention to the substantial distance between all the solutions proposed up to this point and this one, we tend to think that, despite its well-conceived linguistic approach and the outstanding lexical grounds supporting it, it sometimes lacks coherence with the semantic religious-evangelising results, and we are particularly speaking about an absence of a clearer biblical, prayerful or liturgical structure. Nevertheless, it must be noted that, in many of its results, references to the Virgin, the Father (God), Yahweh, the Child, the light, the dawn, the candle, the mercy, the heart, the forgiveness, the offense or the illness-unmistakably Christian religious terms-are used explicitly. Also, without the intention of provoking a debate in further detail with its author, we underline just one philological element: the striking presence of the noun "YHWH", "יהוה", (Yahweh), an odd word within the regular theological-medieval use, which—in spite of having Semitic roots-was unpronounceable with such vowels. That is why the Hebrew people simplified it with the consonants "YHWH", hence our disregarding this theonym in the Insular-Berber language and, therefore, present in the expression underlying in the fragment IAEB, which corresponds to the right side of the cape.

\section{Our Proposal for a Solution}

\subsection{Philological Explanation of the Different Fragments of the Inscription}

We will follow, as a general rule, the wide lexical compilation by Ignacio Reyes (García 2011), supported by other amazigh dictionaries (Basset 1890, 1893; de Calasanti-Motylinski 1898; Dallet 1982; Delheure 1984, 1987; Faidherbe 1877; de Foucauld 1951-1952; Heath 2006; Naït-Zerrad 1998-1999, 2002, 1998-1999, 2002; Prasse et al. 2003; Ritter and Gottfri 2009; Robledo 1944, 1949; Taifi 1991; Taine-Cheikh 2008; van Putten 2014).

\subsubsection{TIEPFSEPMERI}

The root [T·Y] (García 2011, p. 604) in a Berber language like Ayer Tuareg transliteratedly takes a graphemic form $<\mathrm{ti}>$, phonetically / $\mathrm{ti} /$, masculine singular noun meaning father.

The consonantal lexeme [F.G] (García 2011, p. 483) in Tamazight from Central Morocco takes the form <effeg $>$, which can be articulated after an abbreviation process of /ff/ as /f/ and, as is common practice in proto-Berber (Kossmann 2013, p. 56; Takács 2005), the replacement of /f/ with $/ \mathrm{p} /$, justified by a lip obstruction phase, aside from devoiding of velarity the sound $/ \mathrm{g} /$ and placing it on a labiodental phoneme /f/. Thus, the product of the process is /effeg/ > /efeg/ > /epeg/ > /epef/. Morphologically, it corresponds to a verb meaning to reveal/show/discover.

The lexeme [S·B] (García 2011, p. 586) in Tuareg languages such as Ayer or Tawellemmet is represented as <ăsab>, where the consonant $/ \mathrm{b} /$ becomes unvoiced and might sound like $/ \mathrm{p} /$. The meaning of this expression, a noun, is adolescent/virgin.

The next segment, MERI, can be assumed to be a phonetic expression of the proper noun Mary, /maria/, in which the unclean pronunciation of the Canarian people as well as their three-vowel system $\{a, i, u\}$ compared to the five-vowel system of the Latin people $\{a, e, i, o, u\}$, could lead to the interpretation of a value close to /e/ owing to a vocalic closure when listening to the vowel sound /a/ in the first syllable, while /ia/ merge in the second syllable of /maria/, and although the diphthong is broken, it would lead us to think about two separate vowels with a sound produced by the same vocalic closure and closer to / $\mathrm{i} /$ than to /a/ or / ia/. We must note that if we examine (Vera 2016, pp. 324-44) the Marian Evangelical biblical texts by Saint Luke, where we can find the different linguistic forms of Mary's name, we learn that it is written as /meri/ in the Kabyle language, $<$ meryem> (SBI 1995), even when the common rule for Berber languages specifies that the form /mari/ should be used, generally /mariam/. Another option is to guess the lexeme $[\mathrm{M} \cdot \mathrm{R}]<[\mathrm{m}-\mathrm{R}]$ (García 2011, p. 556), with transliterated graphemes <amər>, a verbal singular noun meaning 
grace/joy/cheerfulness/complacency. In such case, the vowel /a/ would be lost by apheresis, at the same time as a shift from / / / to /e/ by frontality occurs, resulting in /mer/.

If we combined each one of the previous elements, we would obtain /ti-epef-ăsap-\{meri/mer\}/. The vowel between /p/ and / $\mathrm{f} /$ may be understood as a pronunciation aid, whereas the short vowel /ă/ may disappear between the preceding and following consonants, thus provoking a new vocalic closure phenomenon during the shift from /a/ to /e/ in the fragment / sap/ > / sep/. For the rest of this set, in the first case we might leave it unchanged, / tie-pf-sep-meri / but, in the second option, we would get the form /tie-pf-sep-mer/. The meaning of the first variation would be, in the SVO syntactic form, The Father (God) reveals/shows the Virgin Mary, main theological expression demonstrating God's role as origin and cause of Mary, given to mankind from Him. In the second case, we might detect some meaning, also in the SVO syntactic form, The Father (God) finds grace in the Virgin, a phrase that makes it compulsory to add one more lexeme at the end, the lexeme [Y] (García 2011, p. 614), which, in a wide variety of Berber languages such as Hoggar Tuareg, Ayer Tuareg or the Tawellemmet, as well as in Teggargrent, Kabyle, Tunzabt or the Tamazight Berber from Morocco, is written in its graphemic form $<i>$, phonetically $/ \mathrm{i} /$, as a morphological element of possessive suffix pronoun in the first person singular me/to me of indistinct gender. This gives shape to the construction Father God has found in me, the Virgin, grace, an expression that resembles the one in Saint Luke's Gospel, chapter 1, verse 30, in the fragment describing the Annunciation by Gabriel the Angel: Feare not, Marie, for thou hast found fauour with God (Bible 1611, p. F2r) (Ne timeas, Maria: invenisti enim gratiam apud Deum (Tvveedale 2005, p. 1308), the latin Vulgata reads). This way, we would obtain the whole expression /tie-pf-sep-mer-i/. Both options fully agree with the importance of the area where it has been engraved TIEPFSEPMERI, the collar or neckline of the image, even though we opt for the latter one because of the sequence of fitting elements with such biblical-theological significance, while also liturgical and devotional, and essential core expression of Mariology.

We would like to point out that the lexemes [F.G] and [S.B] could be replaced with other three different ones: the root [Y.D] (García 2011, p. 614), a verb in the form <yyəd’, as a Berber lexeme, meaning feeling full enough. Its phonetics may undergo a transformation from /iiəd/ to the abbreviation of $/ \mathrm{ii} /$ into $/ \mathrm{i} /$, the vocalic progress from $/ \mathrm{a} /$ to $/ \mathrm{e} /$, and the shift from the coronal /d/ to the labial $/ \mathrm{p} /$, resulting in the final phonetics /iep/. It would be followed by the $\operatorname{root}[\mathrm{F}]<[\Gamma \cdot \mathrm{F}]=[\mathrm{X} \cdot \mathrm{F}]$ (García 2011, p. 481), which corresponds to the preposition over/on, in the form $\langle\mathrm{f}\rangle, / \mathrm{f} /$, in languages like Kabyle, Siwa or Tunzabt. Another possibility is the root [F] (García 2011, p. 481) meaning to find/discover in the form <af $>$ in Berber languages like Figuig, Kabyle, Chaouia, Tunzabt, Teggargrent or Djebel Nefusa, among others, or else $<$ uf $>$ in Awdjila or $<$ if $>$ in Siwa, which allows the considering of a voiced form /V-f/, where the vowel might be dropped by apheresis. The final lexeme would be [S·B·(T)] (García 2011, p. 586), which, in the Ayer Tuareg language becomes <eseəbbi>, a verb meaning to purify, among others. The phonetic form might lose the first vowel by apheresis once again as a mere aid for the pronunciation of the consonants, just as seen in the set /eə/, by abbreviating the two occlusive bilabial consonants and then turning them into the unvoiced sound $/ \mathrm{p} /$, so that, at the end of the process, the final vowel becomes softer in / sep/. This would imply that the whole phonetics of the sequence would be /ti-iep-f-sep/, meaning The Father (God) is brimming with purification on Mary, or else, The Father (God) fill Mary with purification, or also with the other meaning for MERI, The Father (God) is brimming with purity and grace. All of those semantics are concordant with the words included in the verses of the Annunciation by the Angel Gabriel to Mary (Luk 1, 26-38) (Bible 1611, p. F2r), although, in light of the liturgical and biblical argumentation, we prefer God the Father has found in me, the Virgin, grace.

\subsubsection{NARMPRLMOTARE}

The root [M] (García 2011, p. 551) in Kabyle or in Algerian Tunzabt, Berber categorised in the Subgroup Mzab-Ouargla, adopts the form of the grapheme $<\mathrm{m}>$ from the singular feminine belonging 
particle the woman who has/who owns/the owner. Because of the transformation $/ \mathrm{m} />/ \mathrm{n} /$ between coronal and labial nasals, we may consider the form $/ \mathrm{n} /$.

The consonantal root [R] (García 2011, p. 574) in the Ahaggar Berber language adopts the verbal pronominal meaning of fortunate is the one who with a transliterated graphemic form <ere>, even when in languages like Ayer Tuareg the final vowel is dropped and the sound becomes /er/. Besides, its vocalic aperture may lead us to think of the phonetics /ar/.

The lexeme [M] (García 2011, p. 551) conveys as <-m> the possessive pronoun in the suffixed form of the second person feminine singular you/to you, which is phonetically written as $/ \mathrm{m} /$.

The root [F.R] (García 2011, p. 487) adopts the graphemic form <ffer > in languages like Figuig, Siwa or either Algerian or Moroccan Berber languages, corresponding to the verb form meaning to collect/treasure. Phonetics by abbreviation allows us to shift from /ffer/ to / fer/, using the vowel /e/ as a consonantal aid for $/ \mathrm{fr} /$, and which, by labial occlusion, can be retreated to its proto-Berber form $/ \mathrm{pr} /$.

The graphemic form of the root [L] (García 2011, p. 546) in Kabyle or in Hoggar Tuareg corresponds to $<\mathrm{el}>$, which, in turn, can be considered as $/ 1 /$ in our inscription, where the vowel would act as a support for the pronunciation, therefore providing the verbal morphology with the meaning to be related/relatives.

The root [M-T] (Delheure 1987, p. 202) in the Berber language gives us the noun referring to woman, but if the prefix $<t>$ is added, in forms like $<$ tamətțut $>$ in the very Teggargrent singular or $<$ timətțat $>$ in Tunzabt in plural, women. We observe the dropping of the prefix $<\mathrm{t}>$ in transliterated graphemic forms like <məttuti>, Teggargrent again, meaning in a female manner/related to women. We may think of the latter one, which keeps the lexeme [M-Ṭ], shifting from the middle semi-open vowel /ə/ to the back semi-open vowel /o/ and where, due to the marked stress on, /tt/ part of the final vowel $/ \mathrm{i} /$ is lost, and after that consider the abbreviation of the sounds $/ \mathrm{tt} /$ into $/ \mathrm{t} /$, achieving the sound form /motut/, where the consonant $/ \mathrm{t} /$, as is typical with languages like Chaouia, undergoes a series of successive transformations $/ \mathrm{t} />/ \theta />/ \mathrm{h} />\varnothing$. It is for certain that all of the changes hereby discussed are numerous, even though the lexeme is clearly the main element indicating the contents of the inscription on the girdle of the statue.

The lexeme [R] (García 2011, p. 573), being its graphemic form <ar>, which can be pronounced as /er/ by means of vocalic closure without any difficulty, corresponds to the adverb except/unless/if not in a diversity of Tuareg languages such as Hoggar, Ayer or Tawellemmet.

If we bring all the expressions above together, we would have /n-ar-m-pr-l-mota-er/, in accordance with the group of consonantal lexemes or roots of NARMPRLMOTARE, $[M]-[R]-[M]-[F \cdot R]-[L]-[M \cdot T]-[R]$, where the diphthong /ae/ might, due to resemblance, sound like the form /a/ and, at the same time, the end of the phrase might need a vowel, perhaps /e/, as is the case with the preposition until, composed by the graphemes <ar> in Tawellemmet Tuareg or in Ayer Tuareg or in Central Moroccan Berber, and <are > in Tashelhiyt. This would convert the phrase into <narmprlmotare $>$. The meaning of the expression, especially important-just like the previous one-because of the particular spot where it is placed on the girdle of the Marian image, since both the neckline and the waist are seen as privileged areas compared to the rest, the cape and robe, gathers the following elements: this woman is holder-fortunate (blessed/sacred)-you-possess/treasure-kinship-related to women-except, again a syntactic SVO form, which makes us think about the main biblical and prayerful phrase at the beginning of the Hail Mary (I salute you, Mary), a text by Luke found on verse 28, chapter 1 (Bible 1611, p. F2r), Haile thou that art highly fauoured, the Lord is with thee: Blessed art thou among women (Ave gratia plena: Dominus tecum: benedicta tu in mulieribus) (Tvveedale 2005, p. 1308), first part of the Hail Mary prayer as we know it today, along with the part about the encounter of Mary and Isabel, which includes the salutation Blessed art thou among women, and blessed is the fruite of thy wombe (Benedicta tu inter mulieres, et benedictus fructus ventris tui) (Tvveedale 2005, p. 1309), of Luk 1, 42 (Bible 1611, p. F2r), of which Hail Mary entirely consisted until the turn of the fifteenth century in the absence of the second part Holy Mary, Mother of God, pray for us sinners, now and at the hour of our death until that time (Graef 1968, pp. 226-29; Leclercq 1913; Miller 2004, p. 54). Thus, the meaning of our 
sequence on the neckline of the Marian image is clear: You have been blessed with uniqueness among the whole kinship of women, in other words, Blessed are you among women.

\subsubsection{LPVRINENIPEPNEIFANT}

The lexeme [L·F] (García 2011, p. 547) in Ayer Tuareg is written as <əlfu>, a verbal form meaning to accumulate/amass/stock up on. We may transcribe it phonetically as /əlfu/, even though the proto-Berber archaism allows us to transform /f/ into /p/.

The root [R] (García 2011, p. 574) presents the transliterated graphic form <ăr> in Tawellemmet Tuareg as a masculine singular noun accompanying the verb in the same language $<$ ăru $>$, meaning to love for the verb and (thing or person) loved/beloved for the noun.

The root [N] (García 2011, p. 561) in its form <in>, which we find in Tawellemmet Tuareg and the Ayer Tuareg, is a particle placed right beside the verb that indicates a faraway place and means over there/there. It can be expressed by means of the phoneme /in/.

The lexeme [N.F.(Y)] (García 2011, p. 563) is found in Amazigh from Central Morocco in the form <inifif $>$ as a masculine singular noun meaning gap at the bottom of a ravine where water is stored and preserved. If we archaise /f/ as /p/ again, we would get /inipip/, where the first and third vowel /i/ might have acquired a more open sonority like /e/ for an alien compiler, or through local evolution within the Canary Islands, having /enipep/ as result.

The root [N] (García 2011, p. 561) is found in languages like Tawellemmet Tuareg in the form $<a ̆ n>$, or even as $<(\ni) n>$, and it is a suffix for deictic singular nouns or verbs meaning this over here/there.

The lexeme [Y] (García 2011, p. 614) in Ayer, Tawellemmet and Hoggar Tuareg languages presents the transcribed graphemic form <ăy $>$ as a suffix for the possessive personal pronoun in the first person singular me/to me. Phonetically speaking, we may apply vocalic closure to /a/ in order for it to be expressed as /ei/, a feature that has even been contemplated by the aforementioned Tuareg languages.

The lexeme [F] (García 2011, p. 481), meaning to find/discover and with the form <af $>$ is found in Berber languages such as Figuig, Kabyle, Chaouia, Tunzabt, Teggargrent or Djebel Nefusa, among others, or also as $<$ uf $>$ in Awdjila or $<$ if $>$ in Siwa.

The consonantal group [N.T] (García 2011, pp. 569-70) in Hoggar Tuareg is expressed as <ent>, /ent/, a verbal form meaning to be firmly settled on the ground/firmly established or to have deep roots.

If we gather all the elements in the sequence, we obtain the complete phonetics /əlpu-ăr-in-enipep-(ə)n-ei-if-ent/. The vowel /ə/ is not considered as so by some scholars but mere interconsonantal element acting as voicing support (Kossmann 1999, pp. 39-40; Kossmann and Stroomer 1997, pp. 463-64). We may consider the two pseudo-vowels /ə/ as an aid for the pronunciation of the consonants /1/ and /n/. The short vowel /ă/ may serve the same supporting purpose for the /r/ following it, and by abbreviating the group /eii/ into /ei/ and shifting the sound /ent/ to /ant/, with greater vocalic aperture, we would have the final form. After the usual modifications in graphic form of letters such as $\langle\mathrm{u}\rangle$ and $\langle\mathrm{v}\rangle$ in those centuries, we would obtain $<$ lpvrinenipepneifant $>$. The meaning would imply a semantics similar to Accumulating things related to love in the deepest place where what one loves most is kept (a figuration of the heart for occidental people) this one over there is rooted in me, or else, Those who fill their heart and life with love, they are in Me, with a more complex (S)VO syntactic form than other shorter fragments we will see, owing to the use of suffixes in adverbial forms of place and pronoun. The meaning is found in passages referring to the call to the accumulation of treasuries in Heaven and not on Earth, since where your treasure is, there will your heart be also (Mt 6, 19-21) (Bible 1611, p. A4v), as well as to the Command of Love (Mt 22, 37-40) (Bible 1611, p. C3r) and because they are in Christ for that reason, as stated in numerous passages of the Pauline letters (Rm 6, 15-23) (Bible 1611, p. P3r), rooted and built vp in him [Christ], and stablished in the faith, [...] abounding therein with thankesgiuing $(\mathrm{Col} 2,7)$ (Bible 1611, p. T4v) or the Gospel according to Saint John (Jn 15) (Bible 1611, pp. L1r-L1v), among other passages. 


\subsubsection{OLM}

The consonantal lexeme or root [L] $<$ [H·L·H/L] (García 2011, p. 546) corresponds to the verbal form meaning to beg in Tamazight from Central Morocco, with the transliterated graphemic expression $<$ all $>$ and a phonetics we may assume to be $/ \mathrm{al} /$. The text on the carving has only two $<0<$ vowels, one of them hereby considered as a sound $/ \mathrm{o} /$, a rare one in percentage terms, a sign of how uncommon it is linguistically speaking. The sound /o/ does not really belong in the proto-Berber language (Heath 2005; Kossmann 2013, pp. 170-71; Kossmann and Stroomer 1997, p. 472; Prasse 1984, 1990), and so it may come from the assimilation of /au/ or from the sound /ă?/, with the purpose of achieving a greater vowel harmony. As a consequence, it does not seem very unlikely for a third listener to be able to capture sound /ol/.

The lexeme [M] (García 2011, p. 551) expresses as <-m> the possessive pronoun in the suffixed form, second person, feminine singular you/to you, phonetically transcribed as $/ \mathrm{m} /$.

This way, we have /ol-m/, <olm>, meaning We ask you for/we beg you (addressed to the feminine subject that is the Virgin Mary), with a (S)VO syntactic form, an expression that is typical of prayer repertories, and that we can find, for instance, in the Salve Regina (Hail, Holy Queen) prayer: Ad te clamamus (To thee do we cry, which, in Latin, acquires the sense that we are begging while screaming and wailing) (Hexter and Townsend 2012).

\subsubsection{INRANFR}

The lexeme [M.R] (García 2011, p. 556) in the Berber language from Central Morocco becomes $<$ imran>, a plural noun meaning stones embedded into the ground that, like milestones do, demarcate a territory or property, as a form of fencing or boundary wall. It is clear that its phonetic transcription is /imran/, which is phonetically close to /inran/ provided that bilabiality is reduced. With the same consonantal root, we have [M.R] (García 2011, p. 556) also with a similar meaning, as it has the sense of territory/area/region/country.

The root [F-R] (García 2011, p. 487) adopts the graphemic form <ffer $>$ in languages like Figuig and Siwa or in Argelian or Moroccan Berber languages, corresponding to the verb form which means to protect/keep warm/take shelter, as was the case with the aforementioned to collect/treasure. Phonetics by abbreviation allows us to shift from /ffer/ to / fer/, the vowel /e/ serving as consonantal support to /fr/.

By bringing the elements above together, we would obtain the phonetic expression /inran-fer/ or /inranfr/, and it would be our choice to drop or not the supporting vowel for the pronunciation of the final $/ \mathrm{r} /$. The sense of the phrase, Protective wall or Wall that gives us shelter, might slightly evoke the Christian phrase applied to the Virgin Mary as Hortus conclusus (Cant 4, 12), A garden inclosed is my sister, my spouse; a spring shut up, a fountain sealed (Bible 1611, p. 3L5r). In Gregorius Nyssenus (ca. 335-ca. 394), we also find the use of wall/panel to make reference to Mary (Peltomaa 2001), in the sense of her being a protector, especially with a theological meaning related to virginity. A different sense of the expression /inranfr/ might be, as it is placed between the previous expression OLM, and the following one IAEBNPFM-which makes it all the more appropriate-, Protect the territory, the area, in the (S)VO syntactic form, in a begging or pleading-like tone rather than a praising one, as in the previous example.

\subsubsection{IAEBNPFM}

The lexeme [Y] (García 2011, p. 613) in its transcribed graphemic form <i>, and phonetics /i/, is found in Kabyle introducing a clause, meaning the relative pronoun who/which.

The consonantal root [B·B] (García 2011, p. 452) presents the verbal semantics of owner/proprietor/author/master, follows a pronoun and is represented as $<\mathrm{bab}>$ and, consequently, we can make it sound as /bab/. This root is rather close to [B·B] (García 2011, p. 452), with <ebb> form in Ghadames, or $\langle b a b b\rangle$, quite similar to the previous one in several languages from Central Morocco, meaning to carry/hold/provide/support/take responsibility, that is, who has the authority and is in charge 
and is the owner, so we are including both expressions in this case in order to convey the sense of this fragment better. This would lead us to the phonetics / bab/ or /eb/.

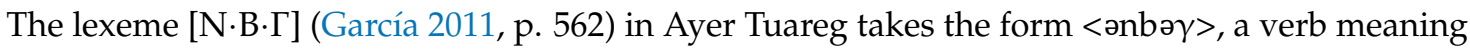

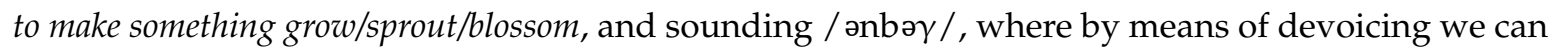
explain the shift from $/ \mathrm{b} /$ to $/ \mathrm{p} /$ while softening the pseudo-vowels $/$ / / as an aid for the pronunciation of the consonants, thus obtaining /np $/$.

The root [G·M] (García 2011, p. 503) is expressed as < where the consonant $/ \breve{g} /$ is a short one, its morphology corresponding to a verb and meaning to sprout/develop/grow.

We have by bringing the elements above together /i-eb-np $\gamma$ - $\breve{g} ə \mathrm{~m} /$, where $/ \gamma \breve{\mathrm{g}} /$ could be abbreviated, converting the velar sound into a more archaic labiodental form /f/, while we may assume that $/$ ə / serves as support to convey the sound of the consonant $/ \mathrm{m} /$. On a different note, the initial vowels /ie/ could, even more when we are working on the lexeme [B.B] and we mention the vowel forms /a/ and /e/, just like /bab/ and /eb/ respectively, phonetise the remaining /iae/ sounds for a collector and transcriber who is not familiar with the language. This way, we would have the form /iaebnpfm/, consistent with the inscription <iaebnpfm>. The meaning of the phrase, with a SV(O) syntactic form, would be Who (this is who) is the author and master that makes (the fields) germinate and grow, an essential agricultural say for the aboriginal people in the Canary Islands, following a theological-creational line in accordance with numerous biblical texts which refer to God as author of the land, the harvests, the growing and germinating of fields, extracted from the Genesis, the Psalms, or the evangelical parables, as gathered in Psalm 104, verse 14: He causeth the grass to grow for the cattle, and herb for the service of man (Bible 1611, p. 3F5v).

\subsubsection{RFVEN}

The consonantal root [R] (García 2011, p. 574) in Ahaggar Berber adopts the pronominal verbal sense of fortunate is the one with the transliterated graphemic form <ere>, although the final vowel is dropped in languages like Ayer Tuareg to become /er/.

The lexeme [F] (García 2011, p. 481) meaning to find/discover and represented by the form <af> in Berber languages such as Figuig, Kabyle, Chaouia, Tunzabt, Teggargrent or Djebel Nefusa, among others, or also $<\mathrm{uf}>$ in Awdjila or $<\mathrm{if}>$ in Siwa, allows us to consider a voiced form /V-f/, where the vowel could be dropped by apheresis or become more relaxed through a process of sound assimilation by a compiler who is not familiar with his language when it merges with the previous /er/ form.

The root [W·N] (García 2011, p. 608) acts as a demonstrative pronoun, either masculine or feminine, where the singular adopts the form $<$ wen $>$, / uen/, in languages like Ayer Tuareg or Tawellemmet Tuareg, meaning this.

By means of unifying the different segments of this part of the inscription, we get /er-V-f-uen/, and so if we make the first vowel softer by placing the main sounding stress on $/ \mathrm{r} /$ and proceeding in the same way with the next vowel, it might convey the sound which speakers with a Latin or Romanic background would pronounce once consonant /r/ and consonant /f/ have been voiced, seeking some support from vowels in order to express them, something that enabled them to safely construct the expression $<$ rfuen $>$, replacing the letter $\langle\mathrm{u}\rangle$ with $\langle\mathrm{v}>$ as was common practice, $<$ rfven $>$. The semantics of the phrase, with a SVO syntax, would translate into something like Fortunate is the one who finds this woman or Fortunate is the one who finds her, referring to the Virgin Mary, or perhaps to the Son, in a sense that resembles the Beautitudes, typical macarisms found all throughout the Bible, especially in the writings by Mt 5, 1-12 (Bible 1611, pp. A3v-A4r) and Luk 6, 20-23 (Bible 1611, p. F6r).

\subsubsection{NVINAPIMLIFINVIPI}

The root [N] > [G·N.(T)] (García 2011, p. 561) takes the graphemic form <ănnu> in the Ayer Tuareg and Tawellemmet Tuareg languages, corresponding to the verb to call/say/name/propose. The initial 
vowel with a short sound /ă/ can be considered as an aid for pronunciation of the consonant /n/, abbreviating the duplicated $/ \mathrm{nn} /$, and resulting in the phonetics $/ \mathrm{n}-\mathrm{u} /$.

In Ayer and Tawellemmet Tuareg, the consonantal root [N.D] (García 2011, p. 563) is expressed through the transliterated graphemic form <inad >, /inad/, a verb meaning to decide/rule/grant authority. The shift from the coronal consonant $/ \mathrm{d} /$ to the bilabial one $/ \mathrm{p} /$ is a transformation that can be seen as a typical one of Berber languages, thus leaving the verb form as /inap/.

The lexeme $[\mathrm{M} \cdot \mathrm{L} \cdot(\mathrm{L})]<[\mathrm{H} \cdot \mathrm{M} \cdot \mathrm{L}]$ (García 2011, p. 555) is found in Tashelhiyt with the graphemic form <imlil> and, therefore <imli(l)>, which implies the phonetics /imli/, deriving from the verb to be good/good-natured, which we convert into and use as a noun, something that is not new in the proto-Berber.

The root [F·N·W/Y] (García 2011, p. 487) in Ayer and Tawellemmet Tuareg adopts the graphemic form <fənəwwət $>$, a qualifying verb meaning to be excessively proud, and which can be converted into a noun through an archaising process, while its initial pronunciation in which the pseudo-vowels / / / act as consonantal support may transform the first one into /i/ through vocalic closure, and make the part / əwwə/ closer to / ui/ by means of the same closure process and also by abbreviating /uu/. The consonant $/ \mathrm{t} /$ undergoes a shift from coronality and labiability as well as an unvoicing during the transformation $/ \mathrm{t} /-/ \mathrm{d} /-/ \mathrm{b} /-/ \mathrm{p} /$, typical of the Berber languages, resulting in the form /finuip/.

The lexeme [Y] (García 2011, p. 613) corresponds to the preposition to/for, which also means against, expressed as $<\mathrm{i}>$ or $<\mathrm{iy}>$ in several Berber languages, such as Ayer Tuareg or Tarifiyt, reason why using the sound form $/ \mathrm{i} /$ is coherent.

By gathering all the elements above, we would obtain the phonetics / nu-inap-imli-finuip-i/ which, transcribed graphemically and after the shift from $<\mathrm{u}>$ to $<\mathrm{v}>$ would be written as $<$ nvinapimlifinvipi $>$. The meaning of the sequence, with a (S)VO syntax, results in It is proposed to grant authority to the good-natured rather than to be excessively proud, in other words and turning to be excessively proud into a noun, It is proposed to grant authority to the good-natured rather than to the proud, an expression that is consistent with a verse in the prayer of Magnificat (Magnify) (Luk 1, 46-55) (Bible 1611, pp. F2r-F2v) by Saint Luke the evangelist, verse 51-52: he hath scattered the proud, in the imagination of their hearts [...] and exalted them of low degree (Bible 1611, p. F2v) (Dispersit superbos mente cordis sui, [...] et exaltavit humiles) (Tvveedale 2005, p. 1309).

\subsubsection{NIPIAN}

The root [M] (García 2011, p. 552) presents the semantics who in the form of an interrogative pronoun, which is graphemically transcribed as $<\mathrm{mi}>$ in Ayer Tuareg, Ahaggar Berber from the Argelian Hoggar mountains, or in Tunzabt, subcategorised into the Mzab-Ouargla, and clearly phonetised as $/ \mathrm{mi} /$.

The lexeme $[\mathrm{F}]<[\mathrm{H} \cdot \mathrm{F} \cdot \mathrm{H}]$ (García 2011, p. 481) takes the form <if $>$ in the Teggargrent language, the Iziyan, belonging in the Zenatic Group, or in Tunzabt, as a verb form meaning to surpass/exceed, which can be transcribed phonetically as /if/.

The root $[\mathrm{Y} \cdot \mathrm{N}]$ (García 2011, p. 615) for the singular indefinite pronoun, meaning some/someone/other is expressed as <əyyăn> in Ayer Tuareg or Berber from Mali Tawellemmet and, consequently, its phonetics / əyyăn/ can turn the two first vowels into the loss of the first one, a much weaker one, leaving aside-since it is indistinguishable—the shortness of the vowel /a/ as /ă/, and unifying the two sounds / yy/ through abbreviation, thus resulting in the sound segment /ian/.

The sound gathering in this fragment could be reduced to /mi-if-ian/, which by merging $/ \mathrm{m} /$ with $/ \mathrm{n} /$, gathering through abbreviation the repetition of the sound $/ \mathrm{i} /$ and by proto-Berber resemblance between $/ \mathrm{f} /$ and $/ \mathrm{p} /$, naturally by labial occlusion, results in the written form $<$ nipian $>$ that, as a whole, means Who-surpasses-someone?/Who is there that exceeds her?/Who is above Him/Her?, with SVO syntax, a form that might derive from the one alluding to God, Quis sicut Deus? or the variant Quis sicut Maria?, Who like ... ? semantics from Saint Michael the Archangel in the first case, as found in Daniel the prophet (Dn 10, 21; 12, 1) (Bible 1611, pp. 4E1v, 4E2v) or the writer of Psalms in 
Psalm 113, 5, Who is like unto the LORD our God (Bible 1611, p. 3G3r), Quis sicut Dominus Deus noster (Tvveedale 2005, p. 635).

\subsubsection{FVPMIRNA}

The lexeme $[\mathrm{F}]<[\Gamma \cdot \mathrm{F}]=[\mathrm{X} \cdot \mathrm{F}]$ (García 2011, p. 481) corresponds to the preposition over in the form $<\mathrm{f}>, / \mathrm{f} /$, in languages such as Kabyle, Siwa or Tunzabt.

The root [W·F] (García 2011, pp. 606-7), in languages like Tawellemmet or Ayer Tuareg, adopts the transliterated graphemic form <ewef $>$, with the sense of the verbal noun fear/panic/terror, and coming from a verbal form with softer vowels, <əwəf $>$, meaning to be afraid/distressed/frightened. Provided that we adopt a softer sonority by turning the vowels /e/ into / / /, serving as support to the consonants, we would obtain the phonetics /euef/>/əuəf/>/ $\varnothing \mathrm{u} \varnothing \mathrm{f} /$. In an ancestral way, we may retreat the sound /f/ until it achieves a /p/ value to produce /up/.

The consonantal root [R.N] (García 2011, pp. 580-81) in Ayer Tuareg language is expressed as $<$ mərna $>$, with the morphology of a verbal noun meaning triumph/victory/superiority. The weak vowel may be turned into a frontal one and, then, through a closure process, transformed into the /i/ phoneme or a similar one, resulting in /mirna/.

If we unify those three elements we would obtain /f-up-mirma/, and by writing the letter $<\mathrm{u}>$ as $<\mathrm{v}>$ we would get the expression $<$ fvpmirna $>$, meaning Over the terror triumph, with (S)OV syntax, or Superiority over terror and fear, with $(\mathrm{S})(\mathrm{V}) \mathrm{O}$ syntax, a typical meaning in the divine theophanies, as gathered by the biblical prophecies, as in Isaiah chapter 41 and verse 10, Fear thou not; for I am with thee [...] I will strengthen thee; yea, I will help thee; yea, I will uphold thee with the right hand of my righteousness (Bible 1611, p. 305v), until the Book of Revelation, Feare not, I am the first, and the last. I am hee that liueth, and was dead: and behold, I am aliue for euermore, Amen, and haue the keyes of hell and of death (Rev 1, 17-18) (Bible 1611, pp. Z4r-Z4v).

\subsubsection{ENVPMTI}

The consonantal root [N.B.(W)] (García 2011, p. 562) in Ayer Tuareg takes the transliterated graphemic form $<$ ənubi(ə)>, singular masculine noun meaning little child.

The consonantal group [N.T] (García 2011, pp. 569-70) in Tuareg from Hoggar is expressed as <ent>, /ent/, a verbal form with the semantics to be firmly settled on the ground/firmly established or to have deep roots, as already seen and as will also be expounded later on, but also with the sense of beginning, hence its meaning origin when used as a noun in the form $<$ enətti(ə) $>$. In this case, we would like to add that this very same place could be occupied not by the lexeme [N.T] but by the root [M] (García 2011, p. 551), which, in many Berber languages such as Kabyle, Tashelhiyt, Tarifiyt, Teggargrent or Tunzabt presents the graphemic form $<\mathrm{am}>$ or $<\mathrm{amm}>$, that may be phonetically transcribed as $\mathrm{/am} /$ and have the meaning of the adverbial comparative syntagm to be the same as/to be like/such.

The root [T·Y] (García 2011, p. 604) in a Berber language like Ayer Tuareg is transcribed into the graphemic form $<\mathrm{ti}>$, phonetically / $\mathrm{ti} /$, of a singular masculine noun meaning father.

By gathering all the previous elements we may think of the phonetic form / ənubi(ə)-ent-ti/ as the first option, in which the first vowel / a/ either adopts the form /e/ through frontality or a similar sound that is capable of gaining support to the next consonant. The consonant / b/ may, by unvoicing, be transformed into $/ \mathrm{p} /$, both considerably resembling each other as occlusive bilabials. The lexeme $[\mathrm{N} \cdot \mathrm{B} \cdot(\mathrm{W})]$ allows for the vowel /ə/, that can join the following vowel /e/ from the lexeme [N.T] to serve as consonantal aid for the rest of the expression. Lastly, and after the shift from $/ \mathrm{n} /$ to $/ \mathrm{m} /$ by replacing coronality with labiality, and also once the two consonants /tt/ are reduced to / $t /$, we are able to express the set as a whole after changing $\langle\mathrm{u}\rangle$ into $\langle\mathrm{v}\rangle$ since that is how such vowel is normally written, as in <envpmti>. As for the other option, and without repeating the previous procedure, / ənubi(ə)-am-ti/ would be the product of merging the sounds / əa/ into an aid vowel that does not appear subsequently in the inscription, perhaps presenting an intermediate vowel aperture between the two vowels, and so, with the same graphemic form <envpmti>. Its syntax, expressed in SVO, 
would mean in the first case The Child (Son) has his roots (origin) in the Father, or The Son has his origin in the Father (God), the second possibility being The Child (Son) is the same as the Father (God). We lack information so as to opt in favour of either one, since both are probably consistent with the biblical and theological-christian data. What we need to do is to convey the divine significance of the Child on the Marian carving, his link to God the Father and his superhuman origin, an aspect we have detected in the Lucan text Luk 1,31-33: thou shalt conceiue in thy wombe, and bring forth a sonne, [...] the sonne of the Highest (Bible 1611, p. F2r), and conversely, in the second option, a more deeply theological aspect emerges: the equality between God the Father and God the Son, to be found in the first verse of the Gospel according to Saint John, In the beginning was the Word, \& the Word was with God, and the Word was God (Jn 1, 1) (Bible 1611, p. I3r), or in the expression of faith by Thomas the disciple in Jn 20, 28, which reads My Lord, and my God (Bible 1611, p. L4v).

\subsubsection{EPNMPIR}

The lexeme [B·D] (García 2011, p. 453) in the form <əbdəd> is found in Ayer Tuareg or in Tawellemmet Tuareg, in which the pseudo-vowel / $/$, acting as a mere phonetic aid, may lead us to the phonetic form /ebdd/, where the consonants /b/ and /d/—both occlusive-are classified in between bilabiality and coronality as a characteristic feature of the Berber languages, and the $/ \mathrm{b} /$ is expressed, by unvoicing, as /p/. From a syntactic point of view, it is a verb that means to raise/lift.

The root [N.N] (García 2011, p. 567) in the same languages that were mentioned above, Ayer and Tawellemmet Tuareg, is transcribed into the graphemic form <ənnun>, a verb meaning to be a docile person/gentle/humble person. As we have already said, the pseudo-vowel / / / can be dropped and considered to be just an aid for pronunciation, while we apply the transformation from labial to nasal coronal between /m/ and /n/, which converts / ənnun/ into / ənmum/.

The root [T·Y] (García 2011, p. 604) corresponds to a verb with the graphemic form $<$ ttey $>$ in a Berber language like the Tamazight from Central Morocco, which can be expressed phonetically as /tei/ after abbreviating the double consonant, and assimilating the vocalic diphthong once vocalic closure occurs in the final expression $/ \mathrm{ti} /$. The transformation $/ \mathrm{t} /-/ \mathrm{d} /-/ \mathrm{b} /-/ \mathrm{p} /$ is not uncommon in the Berber languages, where unvoicing is applied as well as a shifting from coronality to labiality, which leads us to /pi/. It means turn round/overturn.

The lexeme [R] (García 2011, p. 574) with the graphemic form <r> in Kabyle corresponds to the adjective evil/mean/wicked, which can be turned into a noun, a typical feature of the proto-Berber.

If we gather all the previous elements, we would obtain the phonetic form /ep-ənmum-pi-r/, in which we may assume that the vowel $/ \mathrm{u} /$ serves as aid for the pronunciation of the preceding and following consonantal sequence, where if we reduce the double $/ \mathrm{m} /$, dropping the pseudo-vowel $/ \mathrm{a} /$, we get the expression <epnmpir>. The meaning of this fragment would be He raises the humble and overturns the wicked, once the verb to be humble has been turned into a noun, with a (S)VO syntax, that reminds us of another central statement in the Lucan Magnificat prayer (Luk 1, 46-55) (Bible 1611, pp. F2r-F2v), the verse 52: he hath put downe the mighty from their seates, and exalted them of low degree (Bible 1611, p. F2v) (Deposuit potentes de sede, et exaltavit humiles) (Tvveedale 2005, p. 1309).

\subsubsection{VRVIVINRN}

The root [R.W] (García 2011, p. 583) in Tashelhiyt takes the form <uru>, a perfective verb, which may be transcribed phonetically as /uru/ meaning to breed/give birth, that is, has bred in the perfect tense.

The lexeme [Y] (García 2011, p. 613) in its transliterated graphemic form $<\mathrm{i}>$, phonetically /i/, is found in the Kabyle language with the meaning of the demonstrative pronoun who/which, introducing a clause.

The lexeme [W·Y] (García 2011, p. 610) in Moroccan Tashelhiyt captures the meaning of the verb in the aorist form transcribed graphemically as <iwi $>$, which can be expressed phonetically as /iui/, meaning to guide/take to. 
The root [N] (García 2011, p. 561) in its form $<$ n $>$ or $<n n>$, found in the Kabyle language, is a particle referring to a faraway place that is placed right beside the verb and means there. It may be expressed through the phoneme $/ \mathrm{n} /$.

The lexeme [R·N] (García 2011, pp. 580-81) with the graphemic form $<$ rnu $>$ in the Moroccan Izdeg language adopts the verbal morphology of to triumph/win, even though it also appears in the form of a noun in languages such as Kabyle, Tarifiyt and other Riffian languages like $<$ renna $>$, $<$ renni $>$ or $<$ rennu $>$, that is to say $<$ rennV $>$ or $/$ rennV $/$.

By bringing all the fragments above together we may come up with the phonetic structure /uru-i-iui-n-renn-V/. It is likely that, in order to be voiced, the sound expression of the structure [ ... ]NRN will assume some sort of aid like the one offered by our/ ... nrenn-V/. The final vocalic loss could be seen as a softening of the vowel in relation to the preceding consonant, and also as just a support for the voicing of $/ \mathrm{n} /$. On the other hand, the use of the letter $\langle\mathrm{v}\rangle$ instead of $\langle\mathrm{u}\rangle$ is clear in the centuries when the carving was created, as has already been shown in other fragments, and therefore this sequence would undergo the transformation /uruiuinrnV/>/uruiuinrn $\varnothing /$, that is, $<$ vrvivinrn>. As far as semantics is concerned, we would have: She has bred the One who guides us towards victory (salvation), with a SVO syntax, an evidently theological expression including the motives of the Mother and the Son, as well as expressing the idea of the Son as Way, Gate and Guide towards the Salvation and the Triumph, features that are clearly traditional in the Christian theology: I am the doore by me if any man enter in, he shall be saued (Jn 10, 9) (Bible 1611, p. K4r), I am the Way, the Trueth, and the Life (Jn 14, 6) (Bible 1611, p. K6v), or and the sheepe heare his voyce, and he calleth his owne sheepe by name, and leadeth them out (Jn 10,3) (Bible 1611, p. K4r), elements already developed in Psalm 22, especially in Psalm 23, 1-2, The LORD is my shepherd; I shall not want. He maketh me to lie down in green pastures: he leadeth me beside the still waters (Bible 1611, p. 3C3r).

\subsubsection{APVIMFRI}

The lexeme [A] (García 2011, p. 452) in languages such as Teggargrent, Kabyle, Tunzabt, Tawellemmet or Ayer Tuareg is transcribed as $\langle a>$, preceding a clause as a pronoun meaning this one/the one who, and can be specified as the sound /a/ without a doubt.

The $\operatorname{root}[\mathrm{F}]<[\mathrm{F} \cdot \mathrm{W}]<[\mathrm{F} \cdot \mathrm{H} \cdot \mathrm{W}]$ (García 2011, pp. 480-81) in Moroccan Tarifiyt language is transcribed graphemically as <effu $>$, a verb form meaning to dawn/break/shed light/illuminate, which can be phonetically transcribed as /efu/ after reducing /ff/ to /f/ and, as seen in several previous occasions, retreating / $\mathrm{f} /$ towards $/ \mathrm{p} /$ in proto-Berber, resulting in $/ \mathrm{epu} /$.

The consonantal root [N.F.R] (García 2011, p. 563) in languages like Ayer Tuareg or Tawellemmet is expressed as <anfər> with a sense of singular verbal noun meaning extensive/vast, and whose value /anfər/ can be transformed into /infər/ through vocalic closure while, at the same time, a shift from $/ \mathrm{n} /$ to $/ \mathrm{m} /$ occurs, /imfər/, two letters that share a very similar sound due to the labialisation of the coronal.

The lexeme [Y] (García 2011, p. 614) in a wide diversity of Berber languages such as the Hoggar, Ayer and Tawellemmet Tuareg languages, as well as in Teggargrent, Kabyle, Tunzabt or Tamazight Berber from Central Morocco, is expressed graphemically as $<i>$, its phonetics /i/, morphological element of suffix possessive pronoun of the first person singular my/to me of indistinct gender.

If we unify the four parts we would obtain the phonetic expression /a-epu-imfər-i/, whose two vowels /ae/ together can evolve into a sound similar to /a/ through vocalic aperture, while the weakness of the sound / $/$ / produces the sonority $/ \mathrm{f} \varnothing \mathrm{r} /$, and after transforming the graphemic form of $<\mathrm{u}>$ into $<\mathrm{v}>$ would result in $<$ apvimfri $>$. The meaning of the expression, with a syntactic SVO form, would be This one (she or He) is who completely illuminates me, including once again-as was the case with the preceding fragment- - the meaning of the light, and indicating that the Child carried by the Mother, just like the candle, is the one who can eliminate our obscurity, an expression that resembles the popular Dominus illuminatio mea (Tvveedale 2005, p. 561), at the beginning of Psalm 27 (Psalm 27, 1), The LORD is my light (Bible 1611, p. 3C3v), and following the same semantic line of the dedication 
to Candelaria and the Mariological Lucan passages. Also, provided that the subject is the Mother, we must take into account the friar Bonaventura da Fidanza (ca. 1220-1274), the greatest theologian within the family of the Friars Minor (Graef 1968, pp. 275-83) since, in our view and according to our explanations (Vera 2016, pp. 188-225), the Franciscans were the authors of the carving. For a long period of time, he was believed to have written a Psalter addressed to the Virgin Mary (even when we talk about a compilation whose authorship has not been verified, probably diverse yet dating from the thirteenth-fourteenth centuries) that is similar to that included in the Old Testament, but dealing with the Mother of God on this occasion. It showed a hardcore devotion which, nevertheless, was disseminated during the Middle Ages, and included the very same previously referred Psalm that read Domina illuminatio mea (The Virgin Mary (The Lady) is my light) (Cumming 1852, p. 20; King 1840). In addition, the Franciscan friar Conrad von Saxon (s. XIII-1279), in his Speculum Beatae Mariae Virginis (Mirror of the Blessed Virgin Mary), dating from the mid-thirteenth century, deals with the Virgin Mary as the Lady who sheds Light, illuminator, the Illuminatrix (Saxonia 1904).

\subsubsection{PIVNIAN}

The lexeme [F.Y] (García 2011, p. 495) presents the graphemic form <fi> in languages such as Kabyle or Tashelhiyt, in which it is possible to transform /f/ into /p/ by means of archaism, thus obtaining /pi/, a verb meaning to spill/pour/sprout, therefore to germinate/be born.

The root [W] > [G] (García 2011, p. 605), in languages like Ayer Tuareg, corresponds to <əw>, and even to $<\mathrm{iw}>$ in languages like the Tamazight from Central Morocco, and so we may opt for the phonetics /iu/, its meaning being that of a masculine singular particle of filiation equivalent to son of.

The lexeme [N.Y] (García 2011, p. 571) adopts the transcribed graphemic form <ənəy> in Tawellemmet, and also in Adagh Tuareg and Taneslemt, an action verb meaning to dominate/rule/govern, often associated with the divinity as Omnipotent, the Omnipotent (God) in the form of a verbal adjective. Its phonetic form has two vowels / $/$ /, interconsonantal elements acting as voicing support. This way, if the first vowel is dropped through apheresis and the sound of the second one is shifted along with the final sound from / $/ \mathrm{i} /$ to / $/$ / by means of vocalic closure, the result would be the form / $\mathrm{ni} /$.

The root [N] (García 2011, p. 561) is found in languages like Tawellemmet Tuareg in the form $<$ ăn > as a suffix for a singular noun or deictic verb with the semantics this one over here/there.

By gathering the previous elements, we would obtain the phonetics /pi-iu-ni-an/, so by abbreviating the vowels /ii/ and after the shift from $<\mathrm{u}>$ to $<\mathrm{v}>$ owing to the typical Romanised writing, we would get $<$ pivnian $>$. The complete semantics of the sequence would be Born Son of the Omnipotent this One here, with a (S)VO syntax or, once given a more suitable order, This One here is Son born from the Omnipotent, presenting a more complex syntax due to the presence of a particle of filiation, the verbal adjective and the deictic suffix applied to them. It is clear that the text can be identified with that by Luke the evangelist in Luk 1,31-32: thou shalt conceiue in thy wombe, and bring forth a sonne [...] He shall be great, and shall be called the sonne of the Highest (Bible 1611, p. F2r) (et paries filium, [...] hic erit magnus, et Filius Altissimi vocabitur) (Tvveedale 2005, p. 1308).

\subsubsection{NTRHN}

The consonantal group [N.T] (García 2011, pp. 569-70) in Hoggar Tuareg is expressed as <ent>, /ent/, a verb form meaning to be firmly settled on the ground/firmly established or to have deep roots.

The root $[R \cdot H]<[R \cdot Z]$ (García 2011, p. 578), in the very same Tuareg language from the Hoggar mountains, takes the transcribed graphemic form $<$ arəh $>$, a verb form meaning to be well settled/assured/fixed, which can be phonetically expressed as /arəh/.

The lexeme [H·N] (García 2011, p. 529) in languages such as Hoggar Tuareg, Taneslemt, Ayer or Tawellemmet adopts the form <ehən>, which can be phonetised as /ehən/, an expression corresponding to the singular noun housing/establishment/house/lodging.

If we bring the three expressions together, we will have the structure /ent-arəh-ehən/, in which the weak vowels / / / serve as support to the pronunciation of the consonants, and the vowel /a/ before /r/ 
is also an aid for pronouncing it, as is the case with the vowel /e/ preceding /hən/, a common way to express the sound group $<$ ntrhn $>$ among Latin or Romanic language speakers, with the transformations /entar $\varnothing$ heh $\varnothing \mathrm{n} />$ /entarhehn/>/entarhen/>/ntrhn/. The meaning of the expression would be, with a syntax (S)VO, He has established the house well and in a fixed, or else Well-settled and assured house, that is to say, House built on the rock, an expression in line with what was conveyed in the Scriptures: Mary kept all these things, and pondered them in her heart (Luk 2,19) (Bible 1611, p. F3r), his mother kept all these sayings in her heart (Luk 2, 51) (Bible 1611, p. F3v), is the perfect disciple (Luk 11, 27-28), the first who listened to the Word, Christ, to whom she gave birth, thus becoming the person who embraces what she heard, in other words, who has built her house on the rock in contrast with the one who builds his life vpon the sand [...] and great was the fall of it (Mt 7, 24-27) (Bible 1611, p. A5v) (qui aedificavit domum suam supra petram [...] super arenam [...] et fuit ruina illius magna) (Tvveedale 2005, p. 1261).

\subsubsection{EAFM}

The root [H] (García 2011, p. 527), in some Berber languages from Algeria, Niger or Mali may acquire the meaning of to suddenly happen/fall unexpectedly, expressed as <əh $>$ or $/$ / / in Ahaggar Berber and, consequently, due to vocalic frontality and resemblance for a listener who knows no other than the Latin vowels might hear /e/.

The lexeme [F] (García 2011, p. 482) takes the form <af>, /af/, with the sense of the intransitive verb to free oneself/be free in Ahaggar Berber from the Argelian Hoggar mountains, belonging to the Atlas Group.

The root [M] (García 2011, p. 551) indicates the affix pronoun embedded at the end of the word, merged with the preceding verb in this case, in the second person, masculine and plural you, which is expressed by the graphemic form $<-$-əm $>$ or $<-a ̆ m>$, phonetically transcribed properly as /əm/, and highly likely to lose its vocalic sound through apheresis merging the lexemes to $/ \mathrm{m} /$.

This fragment would end up being composed by /e-af-m/, that is, <eafm $>$, presenting a (S)VO syntax, and meaning Our liberation (salvation) immediately come or, in other words, the Kingdom of God as a symbolisation of the expected Messianism, a traditional semitic expression in Jesus of Nazareth's preaching, which encompasses all these elements, a claim we find in the Paternoster (Our Father), Thy kingdome come in Mt 6, 10 (Bible 1611, p. A4v) and Luk 11, 2 (Bible 1611, p. G4v), adveniat Regnum tuum (Tvveedale 2005, pp. 1259, 2005), while it is also how the biblical text ends, with Rev 22, 20: Surely, I come quickly. Amen. Euen so, Come Lord Iesus (Bible 1611, p. 2A6v) ('Etiam venio cito': amen. Veni, Domine Jesu) (Tvveedale 2005, p. 1512).

\subsubsection{IRENINI}

The root [Y·R] (García 2011, p. 615) indicates the noun Moon, expressed as <ayur> in Berber from Central Morocco or in Awdjila, or <yur $>$ in the Figuig or Teggargrent languages, among others, vowel $/ \mathrm{u} /$ that sometimes adopts the sound $/ \mathrm{i} /$, as seen in some plurals of this very same noun, for instance in Tashelhiyt Berber, which can be used to explain the shift from /iur/ to /iir/ or /i:r/, where the long vowel is turned into /ir/.

The lexeme [M·N·Y] (García 2011, p. 556) takes the form of the noun <emnəymənəy> in Ayer Tuareg, meaning shining/gleaming, and in view of the fact that the sound / $/$ / sometimes adopts a neutral sense of consonantal break, we might lose them, all the more when the first and third one already have a sound /i/ following them, plus unifying the nasal consonants from /m-n/ into /n/ through abbreviation, and so losing bilabiality in favour of coronality, an assimilation observed in Berver languages as stated before. This way, we obtain the final sound form /enini/.

The whole set would be phonetically transcribed as /ir-enini/, with the graphemic form <irenini>, and meaning gleaming moon, or with an elliptical verb, you are like a gleaming moon, which can be assumed in the syntactic (S)VO form after including ellipsis of the subject once again. In the Old Testament, the Song of Songs makes reference to the bride as fair as the moon (Cant 6, 10) (Bible 1611, p. 3L5v), pulchra ut luna according to the Vulgata in Latin (Tvveedale 2005, p. 725), a text 
used during the decades when our image was created, and it even appears in comments by Parisian Theologians of St. Victor in the twelfth century (Graef 1968, p. 249). These terms of endearment are sometimes applied to the Virgin Mary, although they are not commonly found in the traditional devotional books, leading to identification with our satellite. However, from the perspective of the insular-Amazigh cosmogony and theology, such designation is rather unsuitable, which leaves us expecting for a more appropriate identification with a star, namely Canopus. In order to find some kind of explanation to this mistake Europeans made when they associate this woman (goddess) with the Moon, we must remember that the first explorers (Vera 2016, pp. 861-75) did talk about the worship of the Sun and the Moon by the native canarians, something we know from Herodotus (fifth century BC), and the apocalyptic reference to the Lady clothed with the Sunne, $\mathcal{E}$ the Moone vnder her feete, and vpon her head a Crowne of twelue starres (Rev 12,1) (Bible 1611, pp. 2A2r-2A2v) is also well known. This led to the recurrent motif in Christian art of the crescent-moon at Mary's feet, occupying precisely the same spot where this inscription, IRENINI, was placed on the carving.

\subsubsection{FMEAREI}

The root [F-N] (García 2011, p. 486), in the form <afna> corresponds to a masculine noun meaning opponent/enemy, at least in the Tashelhiyt language. The sound form /afna/ may make the initial vowel weaker through apheresis to become a mere phonetical aid, then merging $/ \mathrm{n} /$ into $/ \mathrm{m} /$, apart from exchanging phoneme /a/ for /e/ by means of vocalic closure, something that is not unusual, which could lead us to /fme/.

Likewise, the root [R.Y] (García 2011, p. 584) expresses the verb form meaning to protect/shelter, at least in the Amazigh Berber from Morocco and the Central Atlas Group, with the graphemic form $<$ arey $>$ and phonetics /arei/.

It must be noted that Fray Alonso de Espinosa, O.P. (1543-ca. 1600) stated, when dealing with these group of letters placed on the edge of the garment, that not every letter is there, since I believe they have been giving pieces of the robe and the base as relics (de Espinosa [1594] 1980, p. 76). It is unclear whether some letters are missing or not, because he employed the verb believe; however, we assume they are missing indeed, although neither we know nor he specifies if at the beginning of the inscription, in the section EAFM, at the end, in the FMEAREI section, or in the middle, IRENINI. If we pay attention to that very phrase, which the Dominican writes right after the literal sequence on this part of the garment, we may assume that the absence would belong in this fragment, even when we do not have any further supporting argument for that hypothesis.

Now, moving on to the semantics of this last section, of which we would have the structure /fme-arei/, <fmearei $>$, we estimate that there is a need for a better syntactic articulation, perhaps due to the fact that the aforementioned fragment is missing, and a OV(S) or (S)OV syntax, as required by the semantics, which we conceive as From the Enemy (the Devil), save us, an expression in line with the end of the Paternoster, found in the writings by Saint Mathew the evangelist in Mt 6, 13, deliuer vs from euill (Bible 1611, p. A4v), or in its Latin from from the Vulgata, just like a missionary would know it in the fourteenth and fifteenth centuries, libera nos a Malo, syntactically (S)VO, and as gathered in the usual prayer with this text as source, a theme of protection that is also connected to the Mother of God in the apocalyptic sense (Rev 12) (Bible 1611, pp. 2A2r-2A2v).

\subsubsection{NBIMEI}

The consonantal root [N.D] (García 2011, p. 562) means perfect/finished/fair/complete in its Tawellemmet Tuareg form <ăndu>, or <ămdu > in Ayer Tuareg, nominal verb that can be phonetically transcribed as /ăndu/, where the short initial vowel might be disguised as an aid to provide the following consonants with sound. The transformation of the sound /d/ into /b/ is frequent, maintaining occlusivity yet exchanging coronality for labiality.

The lexeme [N.Y] (García 2011, p. 571), in languages like Tawellemmet, presents the graphemic form <ənəy>, a verb meaning to be a visionary/see the future/have clairvoyance. The phonetics, 
with supporting vowels or pseudo-vowels / / / can be expressed as an aid for the first and a shift from the frontality of the mid-vowel / / / to /e/ in the second one, along with the transformation of the nasal $/ \mathrm{n} /$ into $/ \mathrm{m} /$, which results in / əmei/.

By bringing both parts together we would get /ăndu/, really close to / $\varnothing \mathrm{nbu} /$, which together with / əmei/ gives way to /nbu-əmei/, where the vowels /u-ə/ could produce a sound similar to /i/ for a listener who does not know the language through a vocalic frontality process, $<$ nbimei>. With such construction, the meaning of the phrase would be, It is perfect/complete/absolute your clairvoyance (shrewdness), or else, Your wisdom is perfect, You know everything, with an elliptical subject that makes reference to God, and a purely object-oriented syntax with the substantivisation of the two verbs, a very well-known expression within the Christian liturgy that is based on the Psalm 139 (Bible 1611, p. 3H3r), although it can also be applied to the Virgin Mother if we refer to the Marian Psalter in its corresponding variant again (Cumming 1852, p. 75).

\subsubsection{ANNEIPERFMIVIFVF}

The lexeme $[\mathrm{M}]<$ [M·H] (García 2011, p. 552; Prasse et al. 2003, vol. 1, p. 519) has the substantival meaning of mother, being expressed in Taneslemt Tuareg as <anna $>$, phonetically /anna/.

The lexeme [Y] (García 2011, p. 613) corresponds to the preposition to/for, also meaning against, transcribed $<\mathrm{i}>$ or $<\mathrm{iy}>$ in several Berber languages such the Ayer Tuareg or the Tarifiyt, owing to which the sound form / $i$ / is coherent in this case.

The consonantal root [F.R.G] (García 2011, p. 489) has the verbal sense of to protect/take under her protection or else a substantival one, like shelter, graphemically expressed as $<\mathrm{ferg}>$ in Tashelhiyt, with the sound / ferg/.

The lexeme $[\mathrm{F}]<[\Gamma \cdot \mathrm{F}]=[\mathrm{X} \cdot \mathrm{F}]$ (García 2011, p. 481) corresponds to the preposition on/over with the form $<\mathrm{f}>, / \mathrm{f} /$, in languages such as Kabyle, Siwa or Tunzabt.

The lexeme [G.W] (García 2011, p. 514) takes the form <iməggiwa> in its plural noun form in the Tawellemmet language, meaning unsuccessful/losers/unfortunate/less fortunate, which can be phonetically transcribed as /iməuiua/ thanks to the shifting of the sound /g/ to /w/ or / $/$ / through labialisation.

The root [W.F] (García 2011, pp. 606-7) provides the sense of a verbal noun meaning fear/panic, graphemically <əwəf $>$ or $<$ ewef $>$ in Tawellemmet and Ayer Tuareg languages.

By bringing the different parts together into a merged syntactic structure we would obtain /anna-i-ferg-f-iməuiua-əuəf/, where we could consider a transformation of /ai/ into /e/ as an aperture intermediate vowel, a proto-Berber exchange of $/ \mathrm{p} / \mathrm{for} / \mathrm{f} /$, and also the reduction of the sound /gf/ into / f/ through abbreviation and loss of velarity, only to then, additionally, perform metathesis, a phonetic exchange from $/ \mathrm{im} /$ to $/ \mathrm{mi} /$, sometimes common practice in languages yet an evolutive error as well, making the pronunciation of the set / uiua/ easier in the latter case, a set which perhaps will form groups of vowels-some of them weakened-with the next word to achieve / uifuf/ from / uiuaəuəf/, supporting the vocalic sonority with the sound /f/, as one of our choices. This process would result, after exchanging every $\langle\mathrm{u}\rangle$ for $\langle\mathrm{v}\rangle$, in the structure $<$ anneiperfmivifvf $>$. The meaning of the sequence, syntactically SVO, would be something like She is a Mother to shelter the unsuccessful (sinners) and the fear, The Mother is shelter for the sinners and against fear, She is a Mother who protects against failure and fear, an expression that turns out to be more complex than others we have analysed, due to its greater length, unified by the litany A Shelter for sinners (Refugium peccatorum), applied to the Virgin Mary, with fear and terror as terms similar to hopeless/dismayed/in distress and, therefore, to the litany The one who consoles those in distress (Consolatrix afflictorum), even though we should not build our entire theory upon these texts, which appeared after the dates of creation of our carving (Miller 2004, pp. 54-55), between 1425 and 1440 (Vera 2016, pp. 219-25), since they are enshrined expressions dating from the mid-sixteenth century in the Lauretan Litanies, although also elements already shared by the popular piety and used to address the Virgin Mary, as illustrated by the prayer Sub Tuum praesidium (We fly to Thy protection) (Cervera 2001, pp. 21-22, 76; Miller 2004, pp. 54-58), from the third century or even the Salve Regina (Hail, Holy Queen), from the eleventh century (Cervera 2001, p. 75; Evenou 2007; 
Graef 1968, p. 226; Miller 2004, pp. 47, 54, 90), with expressions considerably resembling this fragment placed on the edge of the back of the cape.

\subsection{Final Clarifications and Remarks}

If we take the lexical elements used in their original terms and phonetically expounded, we would have the following set: /ti-effeg-ăsab-amər-i/, / m-er-m-ffer-el-mətțuti-ar-e/ , /əlfu-ăr-in-inifif-ən-ăy-

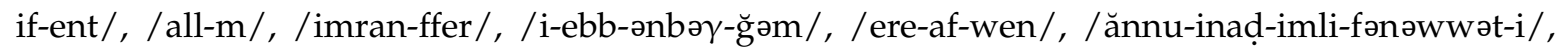
/mi-if-əyyăn/, / f-ewef-mərna/, / ənubi-ent-ti/, / əbdəd-ənnun-ttey-r/, / uru-i-iwi-n-renni/, /a-effuanfər-i/, /fi-iw-ənəy-ăn/, /ent-arəh-ehən/, /əh-af-əm/, /ayur-emnəymənəy/, /afna-arey/, /ăndu-ənəy/, / anna-i-ferg-f-iməggiwa-əwəf/.

In contrast with the original variant of 181 elements, purely graphemic inscribed (TIEPFSEPMERI, NARMPRLMOTARE, LPVRINENIPEPNEIFANT, OLM INRANFR IAEBNPFM RFVEN NVINAPIMLIFINVIPI NIPIAN, FVPMIRNA ENVPMTI EPNMPIR VRVIVINRN APVIMFRI PIVNIAN NTRHN, EAFM IRENINI FMEAREI, NBIMEI ANNEIPERFMIVIFVF), this one presents a total of 260 units.

If we express this sequence in its phonetic form composed by 19 units, $\{/ \mathrm{a} /, / \mathrm{e} /, / \mathrm{i} /, / \mathrm{o} /, / \mathrm{u} /$, $/ \mathrm{b} /, / \mathrm{d} /, / \mathrm{f} /, / \mathrm{g} /, / \mathrm{j} /, / \mathrm{k} /, / \mathrm{l} /, / \mathrm{m} /, / \mathrm{n} /, / \mathrm{p} /, / \mathrm{r} /, / \mathrm{s} /, / \mathrm{t} /, / \theta /\}$, and we compare it with the version of Espinosa's text, which assumes that the graphemes $<\mathrm{v}>$ correspond to $<\mathrm{u}>$ we obtain the chart below (Figure 2):

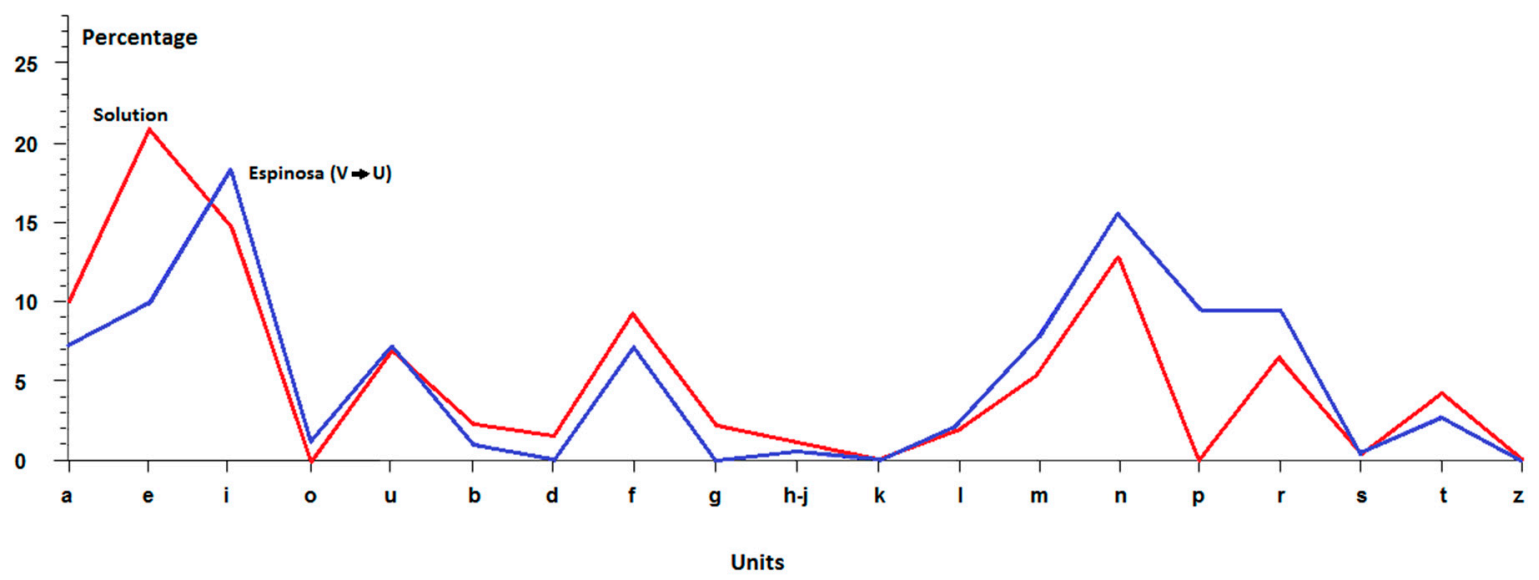

Figure 2. Frequency values of the (19) reduced phonetic units of the original lexical proposal for solution, in contrast to Espinosa's version, in which V is replaced with $U$.

Leaving the percentage differences aside, a great similarity is observed between both charts, something that leads us to be certain that the hypothesis of the text of the Virgin of Candelaria is coherent with the Insular-Amazigh, which presents a wide variety of Berber archaic features. Within the vocalic group, only the letter /e/ experiences differences between both graphics, and that is understandable if we think of the high presence of / $/$ / values, also expressed in the form of the phoneme /e/ in our approach made up by 19 phonemes. The phonemes /b/, /d/, /f/, /g/, /h-j/, $/ \mathrm{k} /, / \mathrm{l} /, / \mathrm{m} /, / \mathrm{n} /, / \mathrm{r} /, / \mathrm{s} /, / \mathrm{t} /$ and $/ \mathrm{z} /$ share a very similar percentage amount. The difference is detected in the phoneme $/ \mathrm{p} /$ owing to, as we have stated before, the transformation into the labiodental fricative $/ \mathrm{f} /$, the voicing of $/ \mathrm{b} /$ or the coronality in $/ \mathrm{d} /$, aspects hereby indicated to which we have added the more infrequent shifting to the voiceless occlusive coronal $/ t /$, all of them being phonemes that have increased their percentage presence as we have been able to learn from the figure above.

In the same manner, this result supports the method chosen by Espinosa through the adoption of the grapheme $\langle\mathrm{v}>$ as letter $<\mathrm{u}>$. Other finer nuances like, for instance, those referring to whether the 
neckline inscription begins as TIEP ... or as ETIEP ... , as gathered in the variants exposed by different authors (Vera 2016, pp. 13-146), is not something easy to solve, since the initial vowel might easily be dropped according to the possible evolution of the Insular Berber lexicon; similarly, on the girdle, whether the beginning is $\mathrm{N}$ or $\mathrm{M}$ is not easy to guess by means of our proposed solution, because both are nasals that can be interchanged without any difficulty.

Going over the syntax of the structures, we have 9 cases with a (S)VO form, even though, on account of the subject ellipsis, we might consider the corresponding $\mathrm{V}(\mathrm{S}) \mathrm{O}$, both being options that can occur in the Berber archaic language. Nevertheless, the group of SVO sentence structures contains 8 components, which leads us to think that the ellipsis in the previous case does not take place in the middle, but at the beginning, having an (S)VO form as a consequence. Afterwards, we have a type $\mathrm{O}$ structure, as well as two cases presenting the options $(\mathrm{S}) \mathrm{OV} /(\mathrm{S})(\mathrm{V}) \mathrm{O}$ on the one hand, and $\mathrm{OV}(\mathrm{S}) /(\mathrm{S}) \mathrm{OV}$ on the other. It strikes us that, if we take into account the proto-Berber syntax (Vera 2016, pp. 832-33), the expected result would have been a VSO form, even the usual one in languages such as Tuareg, or Tashelhiyt or Kabyle, quite numerous in our lexicon. Although the additional argumentations are just a few, this makes us take into consideration the possibility of a segmental translation, performed syntactic section by syntactic section, according to the European methodology for SVO syntax. Another possibility, which we accept with greater hesitation, is that the Insular-Amazigh language followed this syntactic structure. In any event, SVO is clearly the most frequently used form all throughout our text.

Now considering the origin of the lexical forms which have been employed, we have about 87 belonging in the Septentrional Subfamily, even though they are distributed among the Atlas Group and Zenatic Group (41 in the former and 46 in the latter); approximately 80 of them coming from the Tuareg Subfamily; thus leaving us with a far lower amount-just 11—for the Oriental Subfamily (Cabrera 2003; Vera 2016, pp. 322-56). It is not our intention to draw any conclusion from such scarce data, so it must be seen simply as some more information added to the rest of the expounded facts as commented in the introduction, for anything we may say would be too hypothetical, aside from the fact that we ignore the origin of the landings, whether they were more than one, to which islands, the use of native people from different islands in order to create the Marian carving - not necessarily from Tenerife only-, the continental population movements of the Amazigh groups and the ensuing disparity with the current geographic locations, and the linguistic blendings and exchanges within the Berber Subfamilies and Groups (Figure 3), as well as the local transformations within each language, including the Insular-Amazigh.

Finally, focusing on the semantics, on the meaning of the inscriptions and regarding the carving itself and its parts, we may say that there are two particularly preferred spots: the neckline and the girdle. They contain the following expressions:

(Neckline) TIEPFSEPMERI.

God the Father has found in me, the Virgin, grace.

(Girdle) NARMPRLMOTARE.

Blessed are you among women.

The two sequences capture the Mariological nature of the Lucan scene of the Annunciation by Gabriel the Angel to the Virgin Mary (Bible 1611, p. F2r), compiled in the main Marian prayer, the most commonly heard today, the Hail Mary, which at present—of the evangelization of the Canary Islands-is composed just by its first known passage and, in turn, including this first fragment of the Annunciation, Haile thou that art highly fauoured, the Lord is with thee: Blessed art thou among women (Ave gratia plena: Dominus tecum: benedicta tu in mulieribus) (Tvveedale 2005, p. 1308), of Luk 1, 28 (Bible 1611, p. F2r), along with the part referring to the blessed is the fruite of thy wombe, to be found in the salutation of Isabel to Mary, included in the Magnificat by Luk 1, 42 (Bible 1611, p. F2r). 


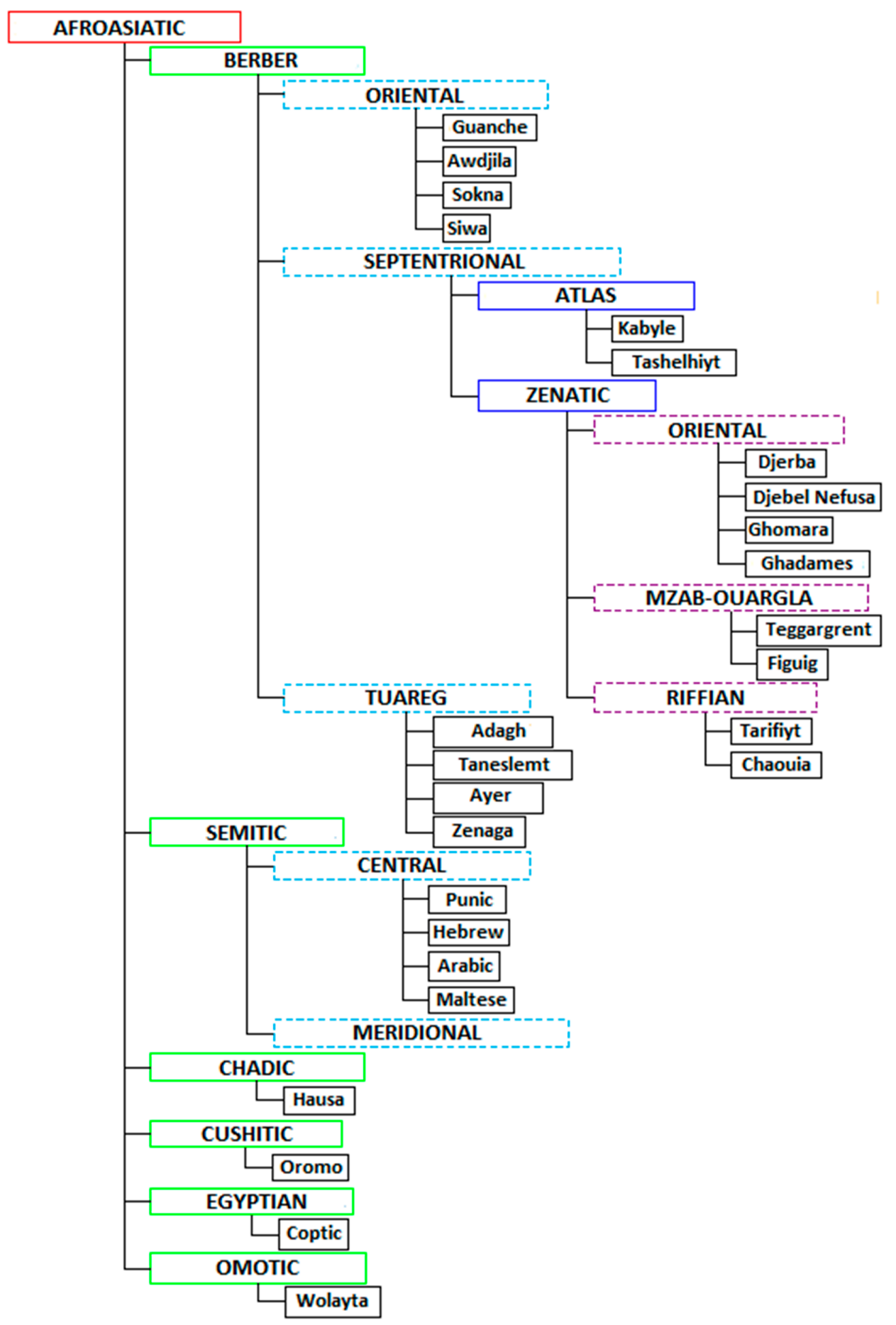

Figure 3. Languages, Subgroups, Groups, Subfamilies and Families of Afroasiatic Phylum (Cabrera 2003; Vera 2016, pp. 322-56).

The rest of areas are considered to be of lesser importance, gathering and developing a series of cathequetical principles addressed to the native aboriginals, in a Mariological and Christological sense, Mother-Child, simultaneously with a concatenation of moral conclusions which arise from this theological revelation.

(Cuff on the candle's side) LPVRINENIPEPNEIFANT.

Those who fill their heart and life with love, they are in Me.

(Right side of the cape) OLM INRANFR IAEBNPFM RFVEN NVINAPIMLIFINVIPI NIPIAN. 
We pray you. Protect the territory. This is the Author and Master who makes [the land] germinate and grow. Fortunate is the one who finds this One. He proposes to grant authority to the good-natured instead of the proud. Who is above Him?/Who is like unto the Lord?

In this case, the question of gender is solved by the semantic sequence in the fourth fragment, which refers to God the Child, as well as the last, the sixth, also referring to Him instead of to his Mother Mary.

(Left side of the cape) FVPMIRNA ENVPMTI EPNMPIR VRVIVINRN APVIMFRI PIVNIAN NTRHN.

Over the terror I triumph. The Son has his origin in the Father [God]/The Child [Son] is equal to the Father [God]. He raises the humble and overturns the wicked. She has bred the One who guides us towards victory [salvation]. This is the one [He/she] who illuminates me completely. This over here is the Son born from the Omnipotent. House built on the rock.

(Garment edge) EAFM IRENINI FMEAREI.

Our liberation [salvation] immediately come/Thy kingdome come. You are like a gleaming Moon. Save us from the Enemy [the Devil]/Deliver us from evil.

(Back of the cape) NBIMEI ANNEIPERFMIVIFVF.

Your wisdom is perfect. You are the Mother who protects against failure and fear.

As we can see, and in line with the importance of the aboriginal culture when it comes to understanding the meaning of the texts, as well as this new and recreated Christian exposition (Vera 2016, pp. 857-71), we find elements referring to Ligth and to the Moon applying to the Virgin Mother, although neither to the stars nor to one star specifically; other elements apply to the significance of a mother figure within the insular canarian pantheon, including features that are typically used to refer to God but are now applied to her. Furthermore, there are references we find in the Psalter of the Blessed Virgin Mary, very frequently used in these centuries (Graef 1968, pp. 276-77, 307, 311), elements that were partly encouraged by the Franciscan observant tendency, devotions to Mary promoted by renowned theologians and seraphic preachers like Antonius Patavinus, O.F.M. (1195-1231), Bonaventura da Fidanza, O.F.M., Conrad von Saxon, O.F.M., Pierre de Jean Olivi, O.F.M. (1248-1298) or Ubertino da Casale, O.F.M. (1259-1338), and also John Duns Scotus, O.F.M. (1266-1308) or Bernardino da Siena, O.F.M. (1380-1444) (Graef 1968, pp. 275-309; Johnson 2007), even though these piety and unction were present ever with Francesco d'Assisi himself (ca. 1181-1226) (Blastic 2007; Esser 1980; Steiner 1981); an observance tradition within Franciscanism, to which we attribute the evangelising mission and the carving (Vera 2016, pp. 188-225). That is why we also find territory, fields, and land-related aspects in our image of Candelaria, as well as a moralising and ethical exhortation to the deeds that are appropriate and expected in the eyes of God and his Mother, together with the protection provided through their proper cult and worshipping, and the rest of expression of theological exposition dealing with the fact that above everything the Child is God and has his origin in God, Father of everything, the Omnipotent. All this can be framed in the relationship with the Mother, essential figure in the Historia Salutis from the Incarnation and its fiat or Amen at the time of the Annunciation, just as the inscription on the neckline and the girdle festoon and the prayer Hail Mary reminds us.

When comparing our proposal (Figure 4) with the previous one by Ignacio Reyes García, there are not many coincidences to be found, the similarities in the use of lexical roots between each solution being scanty: in the sequence TIEPFSEPMERI: [T.Y] (father), [S.B] (virgin), and as one of the possibilities given, the lexeme <meri>; in FVPMIRNA: [R.N] (triumph); for the sequence ENVPMTI: [N.B.(W)] (little child), [T.Y] (father), and as one of the possibilities, the lexeme [M] (equal to); in the case of FMEAREI: [R.Y] (to protect); and lastly, in ANNEIPERFMIVIFVF: [W.F] (fear). For the rest, we could not observe any coincidence in the employed lexemes. On the other hand, his solution sometimes considers the different fragments, a total of 21 , as elements composing a whole sentence by putting several of them together in a sequential manner, although a single fragment may give meaning to a full sentence on some occasions. In our case, a complete ruled structure does exist, in which each one of the 21 sections defines a sentence, consistent with the fact that the author and artist has 
placed them aside from the rest by means of rosettes, fleurons or asterisks, thus showing a coherent phraseological structure.

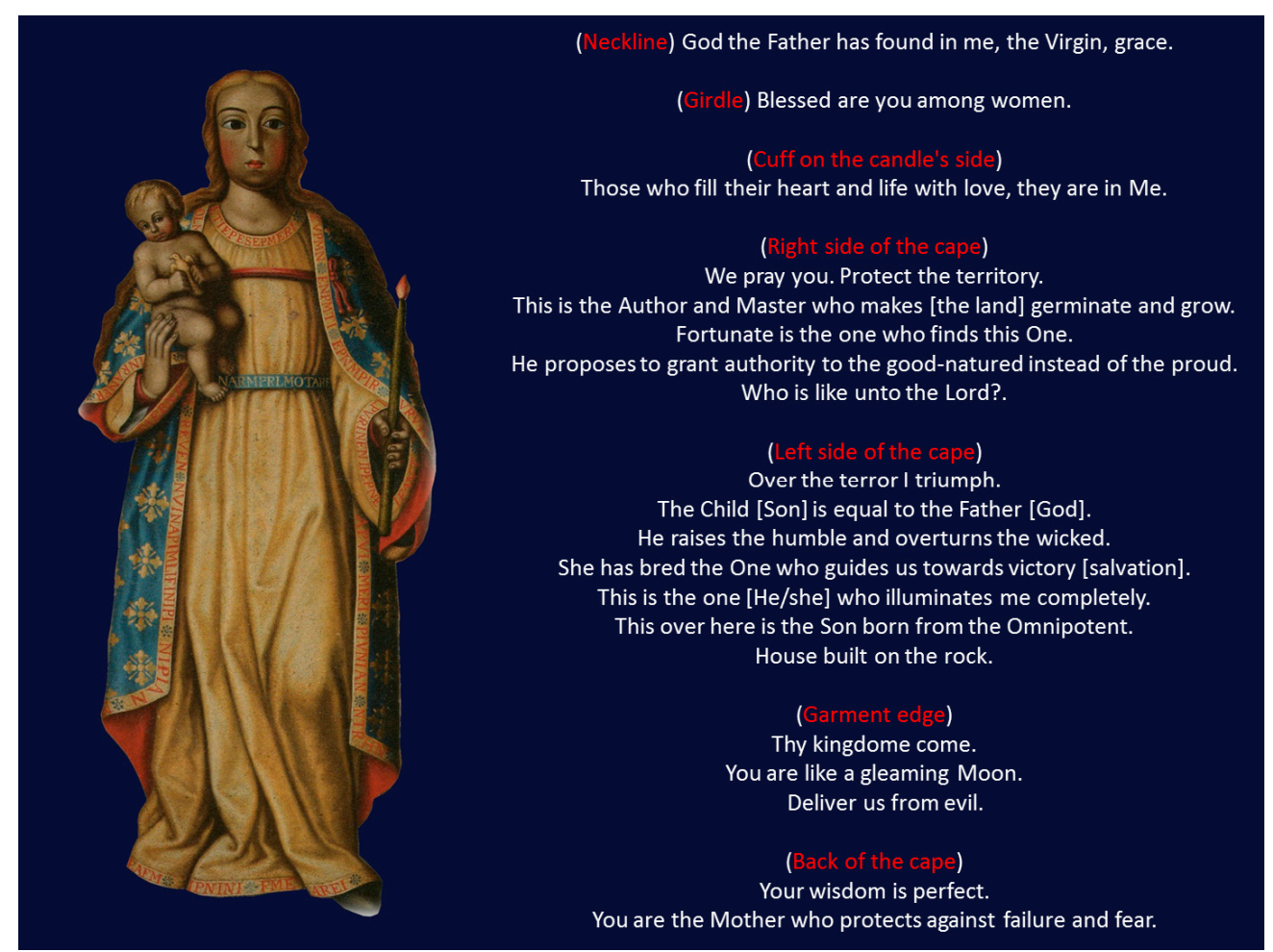

Figure 4. Linguistic decipherment of the lettering on the (original) carving of the Virgin of Candelaria from Tenerife (Canary Islands).

\section{Conclusions}

Will we consider our proposal as the correct solution for the lettering on the original carving of Our Lady of Candelaria? Our answer is evidently and clearly no. At least, not in every section and not in all of its parts. However, we can emphatically affirm, or rather, state with high certainty after our analysis (Vera 2016) that the text makes sense in the Insular-Amazigh language, having a Christian religious meaning; it is neither a meaningless text nor a random inscription, and it is not a ciphered or enigmatic and puzzling text either. In addition, in the light of all of the previously exposed and highlighting the liturgical, biblical and prayerful sense of our proposal, we believe our solution to be a strong candidate to be seen — to some extent—as the possible interpretative solution for the inscriptions of the Virgin of Candelaria, in most sections of the carving, the employed lexemes and roots and in their semantics as well.

Author Contributions: Vicente Jara Vera is the principal author of this research. Carmen Sánchez Ávila has discussed, commented and read the final version.

Conflicts of Interest: The authors declare no conflict of interest.

\section{Abbreviations}

Psalm The Book of Psalms

Cant The Song of Songs

Dn The Book of Daniel

Mt The Gospel According to Matthew 
Luk The Gospel According to Luke

Jn The Gospel According to John

$\mathrm{Rm} \quad$ The Epistle of Paul to the Romans

Col The Epistle of Paul to the Colossians

Rev The Book of Revelation

\section{References}

Abreu Galindo, Juan de. 1977. Historia de la Conquista de las Siete Islas de Canaria. Santa Cruz de Tenerife: Goya Ediciones, pp. 308-9, First published 1676.

Basset, René. 1890. Le dialecte de Syouah. Paris: L'École des Lettres d'Alger, Ernest Leroux.

Basset, René. 1893. Étude sur la Zenatia du Mzab de Ouargla et de L'Oued-Rir. Paris: L'École des Lettres d'Alger, Ernest Leroux.

Bible, King James. 1611. The Holy Bible, Containing the Old Testament, and the New: Newly Translated out of the Original Tongues: E with the Former Translations Diligently Compared and Revised, by His Majesties Special Commandment. London: Robert Barker.

Blastic, Michael W. 2007. Prayer in the writings of Francis of Assisi and the early brothers. In Franciscans at Prayer. Edited by Johnson Timothy J. Leiden: Brill, pp. 16-25.

Cabrera, Juan Carlos Moreno. 2003. El Universo de las Lenguas: Clasificación, Denominación, Situación, Topología, Historia y Bibliografía de las Lenguas. Madrid: Castalia.

Campbell, John. 1901. Critical examination of Spanish documents relative to the Canary Islands, submitted to the writer by Senor Don Juan Bethencourt Alfonso, of Tenerife. Transactions of the Canadian Institute 7: 29.

Cervera, Jesús Castellano. 2001. Santa María en Oriente y Occidente. Barcelona: Centro de Pastoral Litúrgica. Cumming, John. 1852. The Psalter of the Blessed Virgin Written by st. Bonaventure. London: The British Reformation Society. Dallet, Jean-Marie. 1982. Dictionnaire Kabyle-Français: Parler des At Mangellat, Algérie. 2 vols. Paris: Selaf.

de Andrade, Jesús Alonso. 1664. Patrocinio Universal de la Santissima Virgen Maria, Madre de Dios, y Señora Nuestra. Madrid: Joseph Fernandez de Buendia, pp. 454-57.

de Béthencourt Massieu, Antonio. 2004. Idea de la conquista de estas islas (1679): Núñez de la Peña en la historiografía canaria. Anuario de Estudios Atlánticos 50: 886.

de Calasanti-Motylinski, Gustave Adolphe. 1898. Le Djebel Nefousa. Transcription, Traduction Française et Notes Avec Une Étude Grammaticale. Paris: Ernest Leroux.

de Espinosa, Alonso. 1980. Historia de Nuestra Señora de Candelaria. Santa Cruz de Tenerife: Goya Ediciones, First published 1594.

de Foucauld, Charles. 1951-1952. Dictionnaire Touareg-Français: Dialecte de l'Ahaggar. 4 vols. Paris: Imprimerie Nationale de France.

Delheure, Jean. 1984. Dictionnaire Mozabite-Français. Paris: Selaf.

Delheure, Jean. 1987. Dictionnaire Ouargli-Français. Paris: Selaf.

Esser, Kajetan. 1980. Devoción a María Santísima. Oñate: Aránzazu Franciscana, pp. 281-309.

Evenou, Jean. 2007. Las Letanías: Antología, Letanías de los Santos, Letanías de Invocación al Señor, Letanias de Invocación a la Virgen. Barcelona: Centro de Pastoral Litúrgica, pp. 73-78, 91-97.

Faidherbe, Louis Léon César. 1877. Le Zénaga des Tribus Sénégalaises. Paris: Ernest Leroux.

García, Ignacio Reyes. 2010. La Madre del Cielo: Estudio de Filología Ínsuloamazighe. Islas Canarias: Fondo de Cultura Ínsuloamaziq.

García, Ignacio Reyes. 2011. Diccionario Ínsuloamaziq. Islas Canarias: Fondo de Cultura Ínsuloamaziq.

Graef, Hilda Charlotte. 1968. María: La Mariología y el Culto Mariano a Través de la Historia. Barcelona: Herder.

Heath, Jeffrey. 2005. A Grammar of Tamashek (Tuareg of Mali). Berlin: Walter de Gruyter, pp. 34-35.

Heath, Jeffrey. 2006. Dictionnaire Touareg du Mali. Tamachek-Anglais-Français. Paris: Karthala.

Hexter, Ralph, and David Townsend. 2012. The Oxford Handbook of Medieval Latin Literature. Oxford: Oxford University Press, pp. 378-79.

Johnson, Timothy J. 2007. The Prothemes of Bonaventure's sermones dominicales and minorite prayer. In Franciscans at Prayer. Edited by Johnson Timothy J. Leiden: Brill, pp. 109-12.

King, Robert. 1840. The Psalter of the Blessed Virgin Mary illustrated. Dublin: Grant \& Bolton, p. 21. 
Kossmann, Maarten G. 1999. Essai sur la Phonologie du Proto-Berbère (Grammatical Analyses of African Languages). Köln: Rüdiger Köppe Verlag.

Kossmann, Maarten G. 2013. The Arabic Influence on Northern Berber. Leiden: Brill.

Kossmann, Maarten G., and Harry J. Stroomer. 1997. Berber phonology. In Phonologies of Asia and Africa. Edited by Kaye Alan S., and Daniels Peter T. vol. 1, Warsaw: Eisenbrauns, pp. 461-75.

Leclercq, Henri. 1913. Monvmenta Ecclesiae Litvrgica. Paris: F. Didot, vol. 2, pp. 225-27.

Manrique, Antonio María. 1898. La Virgen de Candelaria. La Opinión de Tenerife 1920: 2-3.

Miller, John Desmond. 2004. Mary's Maternal Mediation: Is it True to Say Mary Is Coredemptrix, Mediatrix of all Graces and Advocate? New Bedford: Academy of the Immaculate.

Morales, Carlos Rodríguez. 2009. Catálogo. In Vestida de Sol: Iconografía y Memoria de Nuestra Señora de Candelaria. Edited by Carlos Rodríguez Morales. San Cristóbal de La Laguna: Caja General de Ahorros de Canarias, pp. 142-43.

Morán, José Hernández. 1957. Sobre las letras de la primitiva imagen de la Virgen de Candelaria. Revista de Historia Canaria 117-118: 82-88.

Moure, José Rodríguez. 1991. Historia de Achmaye-Guayaxeras-Achoron-Achaman, Nuestra Señora de Candelaria. Candelaria: Cabildo Insular de Tenerife.

Naït-Zerrad, Kamal. 1998-1999, 2002. Dictionnaire des Racines Berbères (Formes Attestées). 3 vols. Paris and Louvain: Peeters.

Negrín, Alonso Ascanio y. 1899. Ntra. Sra. de Candelaria y lo que Dicen sus Letras. La Orotava: Adolfo Herreros.

Núñez de la Peña, Juan. 1676. Conquista y Antigüedades de la Isla de la Gran Canaria y su Descripción, con Muchas Advertencias de sus Privilegios, Conquistadores, Pobladores y Otras Particularidades en la Muy Poderosa Isla de Tenerife, Dirigido a la Milagrosa Imagen de Nuestra Señora de Candelaria. Madrid: Imprenta Real Florián Anisson.

Peltomaa, Leena Mari. 2001. The Image of the Virgin Mary in the Akathistos Hymn. Leiden: Brill, pp. 191-94.

Prasse, Karl Gottfri. 1984. The origin of the vowels o and e in Twareg and Ghadamsi. In Current Progress in Afro-Asiatic Linguistics. Edited by Bynon James. Amsterdam: John Benjamins, pp. 317-25.

Prasse, Karl Gottfri. 1990. New light on the origin of the Tuareg vowels e and o. In Proceedings of the Fifth International Hamito-Semitic Congress. Edited by Mukarovsky Hans G. Vienna: Afro-Pub, pp. 163-70.

Prasse, Karl Gottfried, Ghoubeïd Alojaly, and Ghabdouane Moham. 2003. Dictionnaire Touareg-Français (Niger). Copenhague: Museum Tusculanum Press.

Ritter, Hans, and Prasse Karl Gottfri. 2009. Dictionnaire Touareg. 2 vols. Wiesbaden: Otto Harrassowitz Verlag.

Robledo, Esteban Ibáñez. 1944. Diccionario Español-Rifeño. Madrid: Verdad y Vida.

Robledo, Esteban Ibáñez. 1949. Diccionario Rifeño-Español (Etimológico). Madrid: Instituto de Estudios Africanos. Saxonia, Conradi a. 1904. Speculum Beatae Mariae Virginis. Quaracchi: Collegii S. Bonaventurae, pp. $25-43$.

SBI (Société Biblique Internationale). 1995. Awal $n$ Tudert: Adlis $n$ Leeqed Ajdid Aked Ihellilen. [Word of Life, Holy Bible: New Testament with Psalms]; Paris: Association Chrétienne d’Expression Berbère.

Steiner, Martin. 1981. San Francisco y la Virgen María. Selecciones de Franciscanismo, 10-28.

Taifi, Miloud. 1991. Dictionnaire Tamazight-Français (Parlers du Maroc Central). Paris: L'Harmattan.

Taine-Cheikh, Catherine. 2008. Dictionnaire Zénaga-Français: Le Berbère de Mauritanie Présenté par Racines Dans Une Perspective Comparative. Köln: Rüdiger Köppe Verlag.

Takács, Gábor. 2005. Some Berber etymologies IV: Lexical roots with *f. Studia Etymologica Cracoviensia 10: 165-93.

Tvveedale, Michaele. 2005. Biblia Sacra Juxta Vulgatam Clementinam. Londini: Conference of Bishops of England and Wales.

van Putten, Marijn. 2014. A Grammar of Awjila Berber (Libya): Based on Umberto Paradisi's material. Köln: Rüdiger Köppe Verlag.

Vera, Vicente Jara. 2016. Contexto, criptoanálisis y propuesta de solución de la inscripción de la talla (original) de la Virgen de Candelaria de Tenerife (Canarias, España). Ph.D. Telecommunications Engineering, Universidad Politécnica de Madrid, Madrid, España, January 27.

(C) 2017 by the authors. Licensee MDPI, Basel, Switzerland. This article is an open access article distributed under the terms and conditions of the Creative Commons Attribution (CC BY) license (http:/ / creativecommons.org/licenses/by/4.0/). 